\title{
A WITTGENSTEIN FOR POSTLIBERAL THEOLOGIANS
}

\section{JASON A. SPRINGS}

Remarkably, the theological discourse surrounding Hans Frei and postliberal theology has continued for nearly thirty years since Frei's death. This is due not only to the complex and provocative character of Frei's work, nor only to his influence upon an array of thinkers who went on to shape the theological field in their own right. It is just as indebted to the critical responses that his thinking continues to inspire. One recurrent point of criticism takes aim at Frei's use of Ludwig Wittgenstein's later work for theological ends. In his recent book Liberalism versus Postliberalism: The Great Divide in Twentieth Century Theology, John Allan Knight challenges what he sees as Frei's dependence on problematic Wittgensteinian assumptions. ${ }^{1}$ This article raises a few concerns about Knight's charges against Frei. ${ }^{2}$ Specifically, I argue that Knight's account tends to conflate the work of Wittgenstein and Frei. It does this by undervaluing two determinative features of Frei's work: (1) its basic Christological orientation; and (2) its Christologically motivated use of ad hoc apologetics. I argue that the Wittgensteinian view that Knight attributes to Frei is not Frei's view at all, and is, moreover, a problematic account of Wittgenstein on its own terms. Finally, Knight's claim that Frei's work "depends upon" and "is suffused" with the understanding of Wittgenstein that Knight attributes to him is based upon an account of Frei's treatment of the sensus literalis that is not entirely accurate. Without question, Knight does remarkable service to Frei's legacy by keeping important debates over his work alive. ${ }^{3}$ In what follows, I propose several points where I think Knight's account might be further enriched. The result, I hope, will be a more nuanced understanding

Jason A. Springs

University of Notre Dame, Kroc Institute of International Peace Studies, 105 Hesburgh Center for

International Studies, South Bend, IN 46556, USA

Email: jspring1@nd.edu

${ }^{1}$ John Allan Knight, Liberalism versus Postliberalism: The Great Divide in Twentieth-Century Theology (Oxford: Oxford University Press, 2013).

${ }^{2}$ In a more recent essay, Knight expands his criticisms to include my own treatment of Frei's uses of Wittgenstein's work. See John Allan Knight, "'Wittgenstein's Web': Hans Frei and the Meaning of Biblical Narrative," Journal of Religion 95, no. 3 (July 2015): 295-432. My explication of, and expansion upon, Frei's uses of Wittgenstein appear throughout my book, Toward A Generous Orthodoxy: Prospects for Hans Frei's Postliberal Theology (Oxford: Oxford University Press, 2010).

${ }^{3} \mathrm{Knight}^{\prime}$ book is bold and ambitious. Its argumentative strategy is forcefully and brilliantly engineered. The present essay focuses solely on some of my disagreements with him. I want to emphasize at the outset that I consider it an excellent book in many regards. Readers unfamiliar with Knight's project 
of the ways that Frei actually appropriated and deployed Wittgenstein's thought. I will contextualize my account of Frei with reference both to Wittgenstein's writings and the literature surrounding his writings. Setting forth these accounts in tandem should help make further available Wittgenstein's work for subsequent work by postliberal theologians.

\section{What's the Use in Calling Frei a Wittgensteinian?}

To deny that Frei was a "card-carrying Wittgensteinian" does not, Knight insists, clear him of these indictments. Indeed, Knight suggests, such a denial may be paradoxical. After all, Frei challenged portrayals of Wittgenstein as forwarding a systematic theory of meaning, and especially any that could be reduced to the aphorism "meaning is use." At the same time, Frei himself was intentionally unsystematic in his use of philosophy, anthropology, and literary theory in his theological work. Therefore, Knight argues, in this important respect (among others) Frei is thoroughly Wittgensteinian. For just as Wittgenstein refused systematic theory-building in his later work, so Frei refused to develop a full-blown theory of meaning (Wittgensteinian or otherwise). Somewhat ironically, then, Frei's very refusal to theorize systematically is what makes Frei Wittgensteinian. ${ }^{4}$ Indeed, Knight goes on to claim that "Frei's critique of liberal theology, his analysis of theological claims, and his own method are thoroughly suffused with, and dependent on, the later Wittgenstein's views on linguistic meaning." 5

Is this portrayal of Frei as Wittgensteinian accurate? Granted, both the later Wittgenstein and Frei are unsystematic in their uses of theory. In this regard, the two share obvious resemblances. At the same time, however, their respective demurrals from theoretical system-building, or the adoption of any comprehensive theory, diverge in fundamental ways.

The value in denying that Frei is a "card-carrying Wittgensteinian" may be clarified by attending more deliberately to the role of Christology in Frei's work, and to the nature and character of what Frei called ad hoc apologetics. Though influenced by both Barth and Wittgenstein (each in different ways), Frei is not concerned to be "loyal" to either. ${ }^{6}$ Frei's motivating and orienting concern is to follow Christ, to be Christocentric from first to last. Indeed, Frei attended to "the gospel narratives" precisely because of the Christological orientation of his theology and his central concern to develop and refine a high Christology. ${ }^{7}$

can find a helpfully lucid synopsis of the argument in Ben Fulford's review of Liberalism versus Postliberalism in Journal of Theological Studies 65, no. 1 (2014): 363-367.

${ }^{4}$ As Knight puts it, "Frei (no doubt intentionally) did not develop any 'Wittgensteinian theory of meaning,' but that very refusal to theorize is shared by Wittgenstein himself" ("Wittgenstein's Web", 338).

${ }^{5}$ Ibid., 359.

${ }^{6}$ Nor is Frei concerned to be a "faithful Barthian." Ibid., 339 and 342. It is true that in his basic Christological orientation, Frei thought Barth was exemplary in many ways. But Frei distanced himself from Barth on certain points, and admitted to interpreting Barth in his own way.

${ }^{7} \mathrm{~A}$ broad swath of scholars has worked to unpack the orientational centrality of Christology in Frei's theology both early and late in his career. For some of the most helpful treatments, see Mike Higton, "Frei's Christology and Lindbeck's Cultural-Linguistic Theory," Scottish Journal of Theology 50, no. 1 (1997): 83-95; and Higton's even more thorough exposition of the Christological commitments and motivations driving Frei's work in Christ, Providence, and History (London: T\&T Clark, 2004); see also Charles Campbell, Preaching Jesus (Grand Rapids, MI: Wm. B. Eerdmans Publishing Company, 1997); Ben Fulford 
Frei found Barth's own scripturally grounded Christocentricity compelling. For, while it refused to predicate theological work upon any univocal, comprehensive theory, or to build a finalized theological system, neither could it be in any systematic way anti-theoretical. In fact, it had to be richly and eclectically theoretical. Because Barth's work, though oriented by the priority of the scriptural witness to Jesus, had to draw upon categories, concepts, and theories external to scripture itself, its use of them would need to be ad hoc and piecemeal. This is not because he privileges the category called "narrative." It is because the object of the scriptural witness is the testimony of God's revelation in Jesus Christ inspired there and then by the Holy Spirit, and which the Holy Spirit makes luminous here and now. It is for similar Christological reasons that Frei's engagement with philosophical resources is ad hoc and unsystematic. Frei understood such an approach to be required by his effort to follow Jesus. Throughout his career he sought to maintain a high Christology as his orientation for engaging scripture and for his exposition of the interwoven-ness of scriptural witness in church practices. In short, Frei's work was motivated by Christology, and not by any concern to take a principled position in a philosophical debate. $^{8}$

Conversely, Wittgenstein was not motivated (as Frei was) by Christological concerns. He had no interest (as Frei did) in the conceptual delicacy and fragmentariness necessitated by, and standing in anticipation of, God's self-revealing action here and now. Nor was Wittgenstein concerned to orient his work according to the injunctions of a subject matter that purports to portray a miracle of grace. Wittgenstein had no concern (as Frei did) to give orientational priority to the presence of Christ through the Holy Spirit making the tasks of theology possible. And so, while there are resemblances in certain features of their approaches, Wittgenstein and Frei diverge in their respective motivations, the ends they pursued, and the effects each sought.

But what of Barth's influence on Frei, which is another central aspect of Knight's critique? It is true that Frei's approach to appropriating theory is one point in which he was influenced by Barth. However, I suspect that Knight's portrayal of the

expounds upon the centrality of Frei's Christology with great clarity in Divine Eloquence and Human Transformation (Minneapolis, MN: Fortress Press, 2013); George Hunsinger's exposition of Frei's Christology, with attention to its basis and development, appears in his "Afterword: Hans Frei as Theologian," in Theology and Narrative (Oxford: Oxford University Press, 1993), and in his article "Frei's Early Christology: The Book of Detours," Pro Ecclesia, 24, no. 1 (2015): 24-36. Hunsinger positions Frei's approach within the broader Christological landscape in "The Daybreak of the New Creation: Christ's Resurrection in Recent Theology," Scottish Journal of Theology 57, no. 2 (May 2004): 163-181. See also my Toward a Generous Orthodoxy, and "Hans Frei's Later Christology: Radiance and Obscurity," Pro Ecclesia, Vol. 24, no. 1 (2015): 37-52.

${ }^{8}$ As he wrote in response to Gary Comstock's pair of articles on his work in the early 1980s (by whom Frei said he had been upsettingly misunderstood), "I am a Christian theologian and do not regard philosophy as ever having achieved that clearly demonstrated set of even formal certainties (and agreements) in 2500 years which would allow it the kind of authoritative status you seem to want to accord it; and yet I believe theology cannot do without philosophy. Furthermore theology cannot even invest so much in the foundational/anti-foundational debate as to come out (qua theology) in principle on the anti-foundational side. Christian theologians will have to make use of philosophy, whichever way philosophers decide that particular issue is to be resolved. In other words, I'm saying two things simultaneously: First, Christian theology is quite distinct from philosophy ... Second, despite their mutual distinctness, theology as a second-order discipline cannot dispense with philosophy, and their relation remains complex and has constantly to be worked out, rather than being of invariable shape." See Frei, "Letter to Gary Comstock," November 5, 1984," in Mike Higton and Mark Alan Bowald, eds. Reading Faithfully, Vol. 1: Writings from the Archives, Theology and Hermeneutics (Eugene, OR: Cascade, 2015), 36-41 (here 37). 
content of that influence-the exact character of Frei's approach-is not entirely correct. Barth did not claim that philosophical (and other) presuppositions and interpretive implements must arise exclusively from within scripture. ${ }^{9}$ Barth claimed, rather, that using insights and presuppositions external to the scriptural witness-as inevitably theologians and readers of scripture must-would need to be re-ordered and oriented by the scriptural witness. This is because the subject matter of the gospels defied conceptual systematization. "For the Gospel is what it is in the divine-human person of Jesus Christ himself. And this person does not permit himself to be translated into a proposition." Hence, as George Hunsinger clarifies, "The explication of revelation will thus always be 'less a system than the report of an event,' and the event concerned will have to be understood under a diversified variety of concepts rather than a unified conceptual scheme."10

By no means does this accordance of primacy to the logic of scripture prohibit the use-or even the necessity-of theory in reading, interpreting, and applying scripture. In fact, just the opposite is true. It recognizes theory's indispensability. However, it also frees the theologian to use any theoretical implements that may help. In fact, it recognizes the need for an eclectic diversity of theoretical implements, though always Christologically oriented. ${ }^{11}$ Thus Barth wrote:

There is none [i.e., no philosophy or method] which must become dangerous [to the scriptural witness], because there is none which we cannot have without positing it absolutely. There is none which cannot possibly become dangerous, because there is none which we cannot posit absolutely, that is, in disloyalty to Scripture erect its presentation into a principle and an end in itself. ${ }^{12}$

\footnotetext{
${ }^{9}$ Knight characterizes Barth's aim as "deriving theological method from the Word of God," Knight, Liberalism versus Postliberalism, 208.

${ }^{10}$ George Hunsinger, How to Read Karl Barth (Oxford: Oxford University Press, 1991), 53 (citing Barth, $C D \mathrm{I} / 1,280)$.

${ }^{11}$ Frei once remarked, "You recall that Barth had said that without some kind of conceptual scheme, some kind of philosophy or general theory, we simply couldn't read. It would be a mechanical exercise, no more than the reiteration of words....[A]pplying a general scheme to specific reading may well be an ad hoc affair, rather than a matter of systematic or tight correlation between text and readings." To explain what this means, Frei quotes Barth at length: "When the interpreter uses the scheme of thought he brings with him for the apprehension and explanation of what is said to us in Scripture, he must have a fundamental awareness of what he is doing. We must be clear that every scheme of thought which we bring with us is different from that of the scriptural word which we have to interpret, for the object of the latter is God's revelation in Jesus Christ, it is the testimony of this revelation inspired by the Holy Ghost, and it can become luminous for us only through the same Holy Ghost" (Frei, Types of Christian Theology [New Haven, CT: Yale University Press, 1992], 85-6 (hereafter Types), quoting Barth, CD, I/2, 730). Frei draws these points from Barth's detailed exposition of the approach to scriptural interpretation ("Freedom Under the Word," CD I/2, 661-740) specifically in the mode of explicatio, meditatio, applicatio (722-740).

${ }^{12}$ Barth, $C D, I / 2,732$. This reflects one of Barth's "rules for reading Scripture" that were so central for Frei's thinking (see Types, 81-6). It is not fully attending to this point that leads Paul DeHart to portray Barth as really a "disguised version of Type 5" (very close to what Knight says of Frei) because it allegedly refuses an independence to "generally accepted concepts" (Paul J. DeHart, The Trial of the Witnesses: The Rise and Decline of Postliberal Theology [Oxford: Blackwell Publishing, 2006], 223). For a succinct account of DeHart's reconstruction of Frei with attention to this point, see Keith Johnson's "Review of Paul Dehart's The Trial of the Witnesses," Scottish Journal of Theology, 64, no. 1 (February 2011): 110 - 111; see also William Placher, "Review of The Trial of the Witnesses: The Rise and Decline of Postliberal Theology," Conversations in Religion and Theology 5 no. 2 (2007): 136-145.
} 
For Barth, the theologian's central task in engaging scripture is thus to orient their use by the centrality of the witness of Christ. This is the account of ad hoc apologetics that most influenced Frei. ${ }^{13}$

Thus, reading Frei accurately requires recognizing that to be unsystematically and eclectically theoretical is not to be "anti-theoretical." Frei's work is richly and eclectically theoretical and thoroughly philosophical. Indeed, Frei insisted that the work of theology needs philosophy and other cognate disciplines. But this need must always be configured in ad hoc and unsystematic ways. Why? Again, this is not, as Knight would have it, because Frei has any principled commitment to following an unsystematic or "ordinary language" reading of Wittgenstein. And it is certainly not because Frei has a principled philosophical commitment to "the failure of descriptivist or referential views of linguistic meaning." ${ }^{14}$ It is, rather, because Frei is committed to following Jesus. The result is richly and pragmatically theoretical-a theoretical posture oriented by, and in service to, the interests and purposes of a high Christology.

Yet Frei's determinative Christological orientation and goal is what Knight's account seems to miss. Indeed, in his treatment of Frei, he refers to Frei's "Christology" only in passing. ${ }^{15}$ More significantly, Knight never, so far as I can see, specifically treats Frei's career-long effort to develop and maintain a high Christological center. This is no minor omission. ${ }^{16}$

Here it is necessary to attend more closely to Knight's project. What, precisely, is at stake in his insistence that Frei ought to, indeed must, be thought of -in terms quite categorical - as committed to, and dependent upon, a Wittgensteinian understanding of meaning? What is the basis for insisting, for instance, that "Frei's critique of liberal theology, his analysis of theological claims, and his own method are thoroughly suffused with, and dependent on, the later Wittgenstein's views on linguistic meaning" ${ }^{17}$

As I read him, this characterization is crucial to Knight's strategy for demonstrating that Frei's theology is a "dead end." ${ }^{18}$ For, if Knight can demonstrate that Frei is motivated by, and beholden to, ordinary language philosophy, with a highly

\footnotetext{
${ }^{13}$ Frei, “Eberhard Busch's Biography of Karl Barth,” Types, 158-62.

${ }^{14}$ Knight portrays this (wrongly, in my view) as "the central postliberal conviction-that descriptivist or referential views of linguistic meaning are fundamentally flawed and therefore should not be used in theology or biblical interpretation...." (Liberalism versus Postliberalism, 224). This claim then becomes the basis for Knight's charge of fideism against Frei (and Lindbeck). He continues, "the strength of this conviction led Frei and Lindbeck to prohibit reference from playing any role at all in determinations of meaning. This prohibition, in turn, prevented Frei from distinguishing adequately between semantic and speech act, and from coherently distinguishing his own theological method from that of D. Z. Phillips. It has also made both Frei and Lindbeck vulnerable of charges to fideism" (224).

${ }^{15}$ Knight, Liberalism vs. Postliberalism, 268-9.

${ }^{16}$ Where Knight mentions Frei's Christology, that treatment is subordinated to what Knight characterizes as Frei's "fear of Feuerbach" and, further, Frei's putative embrace of ordinary language philosophy motivated by his rejection of descriptivist reference (and, thus, the failure of liberal theological method). Several reviewers have noted these features of Knight's account. See, for instance, Ben Fulford's highly charitable synopsis of Knight's project. "[W]hile it is plausible to think Wittgenstein informed Frei's skepticism about general theories, Frei had prior, theological reasons for resisting their application to the gospels, which he articulated consistently throughout his career. Wittgenstein likewise provided warrant for close attention to Christian practices and how meaning and understanding function there, but did not supply Frei with their content." Fulford pinpoints a few further key insufficiencies in Knight's characterization of Frei. See Fulford's Review in Journal of Theological Studies 65, no. 1 (2014): 363-367 (here 366).

${ }^{17}$ Knight, “Wittgenstein's Web," 359.

${ }^{18}$ See Knight, Liberalism vs. Postliberalism, chaps 9-10.
} 
particular reading of Wittgenstein as its basis, then Frei's theological project will be subject to the same devastating criticisms to which that reading of Wittgenstein falls prey.

\section{Frei Against Himself?}

Frei began appropriating insights from Wittgenstein's writings early in his career, but always did so in highly qualified ways. He pointed out, for instance, that Wittgenstein's directive not to "look for the meaning" but rather to "look for the use" has often, as Frei put it, "wrongly been given the status of a general principle." And while traces of Wittgenstein's influence upon Frei are evident across his work, the character and impact of Frei's engagements with Wittgenstein are subtle and require delicate elucidation. Hence, Knight's unqualified characterization of Frei's theology as being "suffused with" and "dependent upon" Wittgenstein's later views of linguistic meaning risks obscuring the nuance and subtleties of Frei's engagement with Wittgenstein's later work.

For instance, Knight ascribes to Frei what appears to be a "meaning is use" general interpretive understanding. ${ }^{19}$ Frei's view of the literal sense, Knight claims, "reveals his commitment to a Wittgensteinian understanding of meaning. This. . .understanding of the literal sense gives to the community the role of the ultimate arbiter of the meaning of any and all biblical texts. That meaning is now indexed to the use of the text in the living out of the community's mission." ${ }^{20}$ With this turn, Knight has made two key moves that inflect his entire treatment of Frei. First, he has identified Wittgenstein with a general understanding of meaning in which meaning reduces to agreement in communal use. Second, he has asserted that this is the general understanding by which Frei identifies the conception of the literal sense that he has embraced by 1982 in his "later work." On Knight's account of Frei, the community uses the biblical text in accord with what it takes to be its mission, thereby conferring meaning upon the text. As such, that community is the "ultimate arbiter" of the meaning of any and all biblical texts.

Frei claimed quite clearly that turning Wittgenstein's adage "look for the use" into a general interpretive principle (e.g. that "meaning is use") is, as Frei put it, "wrong." Of course, it is not unheard of for a thinker to disavow a claim or position explicitly, and then go on to enact some version of it despite her own intentions. Knight does not just cite Frei's passing reference to Wittgenstein; he offers a reading of Frei that purports to further substantiate his characterization. Is Knight's reading a good one?

In my view, two points get Knight's case against Frei moving in the wrong direction. First, it incorrectly ascribes to Frei what I have called "meaning-is-use reductionism," i.e. that the meaning of word or claim-or, in Frei's case, a scriptural text-is conferred upon it by virtue of (i.e. reduces to) the use upon which some community of users agrees-as Knight terms it, "the agreed use" of some community. ${ }^{21}$ This first problem results from overlooking (however inadvertently) Frei's important distinction between the terms "literal" and "plain." Frei deploys this distinction in his discussion of how the literal sense became, was, and ought to be (so Frei argued), the plain sense in the Christian tradition. As I demonstrate in Part III

\footnotetext{
${ }^{19}$ See, e.g., Knight, Liberalism versus Postliberalism, 269 n. 3.

${ }^{20}$ Ibid., 209.

${ }^{21}$ Ibid., p. 211.
} 
below, this error has a sub-part in that it is predicated on a misreading of the passages from Frei's essay "Interpretation and Narrative." This is the basis for Knight's claim that Frei most fully embraces a "commitment to a Wittgensteinian understanding of meaning." I propose that this first difficulty with Knight's case can be corrected by attending more precisely to the orientational role that Frei's Christology plays in his writings on the literal sense. As I will argue, the attribution of anything like "meaning-is-use" reductionism is unfair to Frei. But to deem this reductionism "Wittgensteinian" is to misread Wittgenstein as well.

The second, but related, difficulty facing Knight's account results from what seems to be an over-emphasis of readings of the later Wittgenstein set forth by Scott Soames and Saul Kripke. Specifically, the account of Wittgenstein that Knight attributes to Frei is derived from Saul Kripke's reading of Wittgenstein in Wittgenstein on Rules and Private Language. Perhaps even more influential upon Knight's account of Wittgenstein is Scott Soames' criticisms of a Wittgenstein that looks very much like Kripke's Wittgenstein. ${ }^{22}$ In short, the Wittgensteinianism with which Knight frames Frei's work is a thoroughly Soamesian Wittgensteinianism. I take this second set of problems first. In Part II of this article, I demonstrate how relying upon Kripke and Soames generates difficulties for Knight's analysis of Frei.

I will not defend Frei's theological approach on Wittgensteinian grounds. My purpose is to explicate the relevant philosophical debates over Wittgenstein in order to identify the source of the difficulties encountered by Knight's critical strategy. In short, I find Knight's portrayal of Wittgenstein to be problematic on its own terms. And of course, Knight's portrayal of Wittgenstein is crucial to his analysis of Frei. His aim is to demonstrate (following Kripke's construction, and then Soames' criticisms) that this putatively Wittgensteinian account of meaning is flawed at its core. Knight then portrays Frei's account of the literal sense as intrinsically Wittgensteinian ("about as close to Wittgenstein as a theologian can be" ${ }^{\prime 23}$ ) in these peculiarly Wittgensteinian terms. On that basis, Knight then concludes that Frei's theological account suffers from the same self-defeating defects as purported of Wittgenstein's.

In Part II below I demonstrate that what Knight presents as the "dominant" and "best" reading of Wittgenstein, and the one his critique of Frei presumes, is not an accurate reading of Wittgenstein. It is, rather, a brilliant, but highly idiosyncratic, departure from what Wittgenstein wrote. Neither Frei's unpublished transcripts and archival papers, nor the content of his published engagements with Wittgenstein, give any indication that he deployed that reading. Relying upon this account generates a difficulty in Knight's treatment of Wittgenstein. By implication (given the strategy of Knight's book) it generates a difficulty for his attack upon Frei's putative Wittgensteinianism. Second, it may be the case that Knight's portrayal of Frei ends up looking ever-so-slightly tailored to fit Knight's account of Wittgenstein's views. I address these difficulties by sifting the details of Frei's claims about the nature and basis of the literal sense. My purpose there is to demonstrate the difference it makes to orient these claims by Frei's efforts to foreground a high Christology throughout his career.

\footnotetext{
${ }^{22}$ Scott Soames, Philosophical Analysis in the Twentieth Century, Vol. 2 (Princeton, NJ: Princeton University Press, 2003).

${ }^{23}$ Knight, “Wittgenstein's Web," 339.
} 
There are broader issues at stake here than simply debates among Frei scholars over his use of Wittgenstein's later work, and its continuing usefulness for theological purposes. For Knight's broader research program is implicated as well. He aims to aid theology, and the study of religion at large, by disseminating Scott Soames' work, and deploying Soames' criticisms, throughout the relevant fields of theology and religious studies.

In an earlier article entitled "Why Not Davidson" Knight identifies one of his overarching purposes as introducing Soames' history of twentieth-century analytic philosophy to students and scholars in the study of religion and philosophy of religion. ${ }^{24}$ There, Knight deploys Soames' critical claim that Donald Davidson's account of linguistic meaning (and by implication, his argument against alternative conceptual schemes) is fatally flawed and ought to be rejected. This conclusion applies especially to the relative impact of Davidson's arguments upon scholars of religion. There is some consolation to be found even in this failure, however. For Knight endorses Soames' compliment of Davidson's work that, despite its failure, in the scheme of twentieth-century philosophy it at least "represented a major advance over the antitheoretical bias of Wittgenstein, Ryle, and others." ${ }^{25}$ This putative "antitheoretical bias" is analogous to the "prohibition on systematizing" that Knight attributes to Karl Barth. ${ }^{26}$ Here, Knight risks conflating two distinct phenomena: on the one hand, Barth's theologically motivated demurral from predicating his theological work upon an antecedent philosophical system or comprehensive theory (or even constructing a finalized theological system); on the other, a purported antipathy toward all uses of theory and forms of theorizing (i.e. "anti-theoretical bias"). The former accurately characterizes Barth's approach, while the latter teeters into caricature. Soames inveighs against the same putative antitheoretical bias that Knight attributes to Frei, Lindbeck, and postliberal theologians generally, for purportedly adopting as their starting points Wittgenstein's ordinary language philosophy (and specifically, his rejection of descriptivism). ${ }^{27}$ By Knight's lights, Soames has demonstrated why and how Wittgenstein's account of meaning and reference fail. Demonstrating this failure is a crucial step in correcting what Knight diagnoses as the "bias" (especially regarding "anti-theoretical" accounts of meaning and truth) that has allegedly sedimented across the relevant fields largely through the unfortunate influences of Wittgenstein's later work. ${ }^{28}$

Clearly, Knight takes some risk in following Soames in lockstep as he does. ${ }^{29}$ For if it turns out that the problems in postliberal theology over meaning and truth that Soames (and Knight) diagnose as emerging from Wittgenstein are not, in fact, based

\footnotetext{
${ }^{24}$ John Allan Knight, "Why Not Davidson: Neo-pragmatism in Religion and the Coherence of Alternative Conceptual Schemes," Journal of Religion 88, no. 2 (April 2008): 159-89. In contextualizing Knight's analysis of Frei within his broader interests and purposes stated in this earlier essay, I do not mean to suggest that I think his attack on Davidson succeeds.

${ }^{25}$ Ibid., 187-88 n. 77; for replication of these charges, see Knight's Liberalism versus Postliberalism, 146.

${ }^{26}$ Knight, Liberalism versus Postliberalism, 12.

${ }^{27}$ Ibid., 227-28.

${ }^{28}$ See Knight, "Why Not Davidson," 160 n.2; 187-88 n. 77.

${ }^{29}$ Knight deploys Soames' arguments from Philosophical Analysis in the Twentieth Century throughout “Why Not Davidson" 160; 171 n. 45; 173 n. 48; 178 n. 57; 181 n. 67; 185 n. 74; 186 n. 75-76; 187-88 n. 77; Liberalism Vs. Postliberalism, 41 n. 6; 140 n. 2; 142 n. 4; 144-46; 230 n. 4; 234 n. 13; 245 n. 45; and “Wittgenstein's Web," 339 n. 12; 340 n. 14-16.
} 
on accurate accounts of Wittgenstein, then Knight's repudiation of Wittgensteinand his repudiation of thinkers who hold to such putatively erroneous Wittgensteinian views (e.g. Frei)—will also encounter difficulties. In the remainder of this essay, I argue that Knight's attack on Frei encounters difficulties for these reasons. I then propose to amend Knight's account by reexamining Frei's uses of Wittgenstein by contextualizing them within Frei's broader Christological concerns. Doing so, I suggest, makes evident his use of ad hoc apologetics. The implications are broad enough to warrant precise grasp of the character of the philosophical claims which appear to create difficulties in Knight's account of Frei. ${ }^{30}$ Thus, I first explicate Kripke's portrayal of Wittgenstein, attending to precisely why it is so profoundly controversial as a reading of Wittgenstein. I then examine how these controversies are reflected in Soames' repudiation of Wittgenstein. I then examine how these both inflect Knight's argument against Frei.

\section{Kripkenstein's Web}

Saul Kripke's Wittgenstein on Rules and Private Language generated three distinct, but interrelated, philosophical controversies: 1) a "skeptical paradox" Kripke derives from Wittgenstein's treatment of "following a rule," 2) a "community view" account of meaning Kripke derives from Wittgenstein's putative "skeptical solution" to this "skeptical paradox"; and finally, 3) Kripke's account of the so-called private language argument in the Philosophical Investigations (PI). In this section, I briefly describe each in turn. In the following section I explore possible ways of navigating each controversy drawn from Wittgenstein's writings. Then I examine the relevance of each response for accurately understanding Frei's actual engagement with Wittgenstein.

Kripke identified what he called the "skeptical paradox" in Wittgenstein's account of following a rule (PI, para. 201). In this passage Wittgenstein imagines himself confronted by a skeptic. "This was our paradox," Wittgenstein writes:

[N]o course of action could be determined by a rule, because every course of action can be made out to accord with the rule. The answer was: if everything can be made out to accord with the rule, then it can also be made out to conflict with it. And so there would be neither accord nor conflict there. ${ }^{31}$

Kripke took Wittgenstein in this passage to embrace the validity of the "skeptical paradox," and proposes, in response, a "skeptical solution."32

\footnotetext{
${ }^{30}$ Indeed, many theologians may be unfamiliar with Kripke's treatment of Wittgenstein, as (arguably) it has received considerably less attention in theological circles compared to the degree it has been engaged in philosophical circles. In one of the more widely cited accounts of Wittgenstein's work for theological purposes, Fergus Kerr sets forth a meticulously exegetical account of Wittgenstein's writings with an eye toward their relevance for Christian theology. In this Kerr consigns Kripke's Wittgenstein (and the controversies that swirl around it) to a footnote, gesturing toward the repudiation of this putative reading of Wittgenstein by Colin McGinn, Wittgenstein on Meaning. See Fergus Kerr, Theology After Wittgenstein (Oxford: Blackwell, 1986), 110.

31 "This was our paradox" refers to Para 198: "But how can a rule shew me what I have to do at this point? Whatever I do is, on some interpretation, in accord with the rule. That is not what we ought to say, but rather: every interpretation, together with what is being interpreted, hangs in the air; the former cannot give the latter any support. Interpretations by themselves do not determine meaning" (PI §198).

${ }^{32}$ Saul Kripke, Wittgenstein on Rules and Private Language (Cambridge, MA: Harvard University Press, 1982), 8 .
} 
The "skeptical paradox" emerged from the reading of the preceding paragraphs of the PI (to which Kripke understands para. 201 to be the conclusion). On Kripke's reading, to follow a rule entails properly interpreting the meaning of that rule. Of course, any such interpretation will itself have to be guided by an interpretation of a prior rule that directs the interpretation of the rule in question. But proper interpretation of that prior rule also depends upon proper guidance by an antecedent rule that must itself have been properly interpreted, and will also require an interpreted directive, so the regress continues ad infinitum. There is no fact-and one thus has no guarantee - that what I interpret the meaning of, for instance, the ' + ' sign in a mathematical calculation to be at a given point in time is (will be/was) the same meaning that it had in any previous instance (or will have in any future instance). ${ }^{33}$ As Kripke puts the point, "it seems that no matter what is in my mind at a given time, I am free in the future to interpret it in different ways." 34 The result is interpretive indeterminacy. In Wittgenstein's words, if "everything can be made out to accord with the rule, then it can also be made out to conflict with it. And so there would be neither accord nor conflict there" (PI 201, para. 1). Here, Wittgenstein allegedly demonstrates that "going on in the same way" in what words mean is an appearance that floats only on the surface of community relations, but for which there are no grounding facts or determining directives. Indeed, Kripke writes, "Wittgenstein's main problem is that it appears that he has shown all language, all concept formation, to be impossible, indeed unintelligible." ${ }^{35}$

Of course, as Kripke has it, Wittgenstein refuses to let this skeptical paradox win the day. Thus, Kripke claims, Wittgenstein answers the "skeptical paradox" with a "skeptical solution"-namely, the claim that ordinary language does not need ultimate justification (e.g. of the kind that Wittgenstein had attempted in the Tractatus). For even though the skeptic about rule following cannot be answered on his own terms, nonetheless, the fact remains that ordinary language use somehow holds together and is mostly successful for communication. The meanings of the words that are shared by a community of speakers are more or less settled and reliable. Kripke's Wittgenstein points to community members' agreements upon their uses of ordinary language as all they need to sidestep the skeptic's paradox about rule following. To answer the "skeptical paradox" about rule following, one need only appeal to a community's agreed upon uses of its words (i.e. a word's agreed role within a community's form of life).

With this "skeptical solution" Kripke portrays Wittgenstein as forwarding a "community view" account of meaning that need do no more than describe the agreed upon roles that a community's words play in its form of life. On this account, it is possible to follow a rule that everyone-or most everyone-else agrees with, though not possible to provide grounds for following that (or any) rule. In other words, the possibility of following a rule now requires only an individual community member's adapting to and speaking in accord with the "assertability conditions" of his or her community. Why strive for self-certifying facts of meaning when an understanding of meaning as the agreed upon use of a word in the context of a community's ordinary language will be perfectly sufficient? Or, as Knight helpfully

\footnotetext{
${ }^{33}$ Ibid., 272-3.

${ }^{34}$ Ibid., 294.

${ }^{35}$ Ibid., 62.
} 
restates this position: "In that case, all that is required for a sentence to have meaning is that there be roughly specifiable circumstances under which it is legitimately assertable [i.e. that its assertability is warranted, or in effect, warranted assertability regarding meaning], and that the game that involves its assertion plays a role in our lives." 36

Notice that on this "community view" account, meaning is a species of agreed upon social (communal) use. How can I be said to know that the symbol ' + ' in a mathematical equation means that I am to add together the two numbers that it stands between? Kripke's answer is that the community in question agrees that ' + ' means addition: "Smith will judge Jones to mean addition by 'plus' only if he judges that Jones's answers agree with those he intended to give." ${ }^{13}$ And further, "if the individual no longer conforms to what the community would do in these circumstances, the community can no longer attribute the concept to him." 38 What follows from the assertability conditions of communally agreed upon use is not "that the answer everyone gives to an addition problem is, by definition, the correct one, but rather that platitude that, if everyone agrees upon a certain answer, then no one will feel justified in calling the answer wrong." ${ }^{39}$ In short, in this community the symbol ' + ' is correlated with the collective inclination to respond to it by 'adding' the numbers that stand on either side.

Moreover, if (as a good Wittgensteinian therapeute) I am pressed by the skeptic for justification as to how I know with certainty what ' + ' means, at some point my justifications give out, and I say "Back off, dude....this is just what we do!" At that point I can give no reasons. In fact, ultimately (and perhaps in most cases) I follow the rule "blindly." I just do what I have come to be inclined to do as a participant in the community in question, and can give no justification. So Kripke:

The entire point of the skeptical argument is that ultimately we reach a level where we act without any reason in terms of which we can justify our action. We act unhesitatingly but blindly. This then is an important case of what Wittgenstein calls speaking without 'justification' ('Rechtfertigung'), but not 'wrongfully' (zu Unrecht'). It is part of our language game of speaking of rules that a speaker may, without ultimately giving any justification, follow his own confident inclination that this way (say, responding '125' [when asked for the sum of 68 and 57]) is the right way to respond, rather than another way (e.g. responding '5') [which would be right on an another function ("quus") one which Kripke shows cannot be ruled out as the one being acted on]. That is, the

\footnotetext{
${ }^{36}$ Knight, Liberalism versus Postliberalism, 147 (italics added). Knight takes me to task for guarding against the ascription of a kind of "warranted assertability" about meaning to Frei's uses of Wittgenstein. I use this term to describe what I elsewhere refer to as "meaning is use" reductionism. On this position, the meaning of one's word or sentence is indexed to "whatever your peers will let you get away with" (i.e. what they will agree, or recognize in practice, the meaning of those words and sentences to be). Knight takes this as a misplaced literal invocation of John Dewey or Richard Rorty's understanding of "truth as warranted assertability" (it is not). Otherwise he cannot think of whose position it might apply to, and thus characterizes my use of that phrase as metaphorical. While I did not have his understanding of Wittgenstein in view at the time, I consider my account of that position to apply to his Kripkean construal of Wittgenstein with what Knight calls "legitimate assertability" at its heart.

${ }^{37}$ Kripke, Wittgenstein on Rules and Private Language, 91.

${ }^{38}$ Ibid., 95

${ }^{39}$ Ibid., 112.
} 
'assertability conditions' that license an individual to say that, on a given occasion, he ought to follow this rule this way rather than that, are, ultimately, that he does what he is inclined to do. ${ }^{40}$

One responds to the question of truth by appealing to justification conditions. If pressed, one simply replies, "this is what I am inclined to do," and this on the basis of "this is what we do." In effect saying, "I have come to be inclined to do what the community is inclined to do." ${ }^{\prime 1}$ Thus, the community consensus account of meaning that Kripke attributes to Wittgenstein's "skeptical solution" always and necessarily stands at a remove from what could be asserted as truly the case. It is always, rather, what "we agree to be the case." On this view, meaning and truth are reducible to what the community of asserters agrees is warranted as assertable (in Knight's preferred inflection of this phrase, "legitimately assertable ${ }^{\prime 42}$ ) within the community, i.e. the "brute," non-normative givenness of its form of life. ${ }^{43}$

Finally, Kripke takes as a corollary of Wittgenstein's putative "skeptical solution" to the "skeptical paradox" that there can be no such thing as a "private language." 44 As we have just seen, the "skeptical solution" was predicated upon the individual's accord with the community's explicit agreement. As such, the "skeptical solution" is "inapplicable to a single person considered in isolation." ${ }^{45}$ For, in order for the words of such a language to have meaning, they must conform to the uses that the members of the linguistic community in question agree upon. On this understanding, any attempt to devise a language singly, as an individual in isolation from a community of fellow-users, would be impossible. On Kripke's "community view" reading of Wittgenstein's private language argument, a language speaker cannot speak a language in isolation. This is because the words of the language have their meaning conferred upon them by agreement upon that meaning by the community of users. Speaking a language at all requires speaking it in accord with a community of speakers.

\section{Why Not Kripke?}

Kripke initially delivered his lectures in 1976, and published them under the title of Wittgenstein on Rules and Private Language in 1981. A cascade of rejoinders-from critics and defenders alike-pointed out that Kripke's account of Wittgenstein on "following a rule" was rather abstracted from anything Wittgenstein actually wrote in the PI. ${ }^{46}$ In fact, part of what made it a richly generative philosophical text in the

\footnotetext{
${ }^{40}$ Ibid., $87-8$.

${ }^{41}$ This formulation overlays PI para. 217 over Kripke's construal of Wittgenstein: "If I have exhausted the justifications I have reached bedrock, and my spade is turned. Then I am inclined to say: 'This is simply what I do'." In his lengthy repudiation of Kripke's Wittgenstein, Stanley Cavell points out that Kripke's reading, in effect, rewrites para 217 to read: "If I have exhausted the justifications I have reached bedrock, and my spade is turned. Then I am licensed to say: 'This is simply what I am inclined to do.'" Stanley Cavell, Conditions Handsome and Unhandsome (Chicago, IL: University of Chicago Press, 1990), 69-70.

${ }^{42}$ Knight, Liberalism versus Postliberalism, 147.

${ }^{43}$ Ibid., 148, 207.

${ }^{44}$ Kripke, Wittgenstein on Rules and Private Language, 62.

${ }^{45}$ Ibid., 79.

${ }^{46}$ To name a few examples among many: Peter Winch, "Critical Study of Kripke (1982)"; G. E. M. Anscombe, "Critical Notice of Kripke (1982)"; Colin McGinn, Wittgenstein on Meaning (Oxford: Blackwell,
} 
1980s was that Kripke was entirely forthcoming that his treatment of Wittgenstein neither reflected, nor really even attempted, an accurate engagement with the text of Wittgenstein's PI. "My method is to present the argument as it struck me, as it presented a problem for me," he explained in response to such concerns in a preface to the 1982 edition of the text. "Probably many of my formulations and recastings of the argument are done in a way Wittgenstein would not himself approve. So the present paper should be thought of as expounding neither 'Wittgenstein's' argument nor 'Kripke's': rather Wittgenstein's argument as it struck Kripke, as it presented a problem for him." ${ }^{48}$ And indeed, Kripke's reading is so idiosyncratic and at odds with the actual text of the PI that it has come to be broadly referred to in the surrounding literature as KW ("Kripke's Wittgenstein") and, perhaps more felicitously, as "Kripkenstein." ${ }^{49}$ Where, precisely, does it part company from the PI?

Perhaps the most significant point at which Kripke leaves off from the text of the PI occurs where Kripke offers an account of the "skeptical paradox" about rule following. The skeptical paradox Kripke derived from the first part of PI 201 was not (pace Kripke) a position that Wittgenstein validated. Nor does Wittgenstein even treat it as a problem needing to be answered. In fact, in the second part of paragraph 201 Wittgenstein claims just the opposite of what Kripke attributed to him. Thus, reading the two parts of paragraph 201 together fundamentally challenges Kripke's portrayal of Wittgenstein.

[Part 1: the portion that Kripke acknowledges] This was our paradox: no course of action could be determined by a rule, because every course of action can be made out to accord with the rule. The answer was: if everything can be made out to accord with the rule, then it can also be made out to conflict with it. And so there would be neither accord nor conflict there.

[Part 2: the portion that Kripke does not acknowledge] It can be seen that there is a misunderstanding here from the mere fact that in the course of our argument we give one interpretation after another; as if each one contented us at least for a moment, until we thought of yet another standing behind it. What this shows is that there is a way of grasping a rule which is not an interpretation, but which is exhibited in what we call "obeying the rule" and "going against it" in actual cases." $^{\prime 50}$

The problem that Kripke identified as vexing Wittgenstein was actually one Wittgenstein attributed to his imagined interlocutor and then dismissed as an

1984); G. P. Baker and P. M. S. Hacker, Skepticism, Rules and Language (Oxford: Basil Blackwell, 1984); John McDowell, "Wittgenstein on Following a Rule," Synthese 58 (1984): 325-63; David Pears, The False Prison, Vol. II (Oxford: Oxford University Press, 1988), Chapters 16-17; Stanley Cavell, Conditions Handsome and Unhandsome, Chap. 2.

${ }^{47}$ Kripke, Wittgenstein on Rules and Private Language, 1982, viii.

${ }^{48}$ Ibid., 5.

49 “Kripke's book was the starting-point for a debate about 'Kripkenstein' on rule-following, a debate which is now conducted largely in blissful disregard for Wittgenstein's own writings (see Miller and Wright 2002 [Alexander Miller and Crispin Wright, eds., Rule Following and Meaning (Montreal and Kingston: McGill-Queen's University Press, 2002])." Hans-Johann Glock, “Wittgenstein's Later Philosophy," in Michael Beaney, ed., The Oxford Handbook of the History of Analytic Philosophy (Oxford: Oxford University Press, 2013), 587.

${ }^{50}$ Wittgenstein, PI, Para 201. 
obvious misunderstanding ("It can be seen that there is a misunderstanding here..."51). Yet by taking seriously the "skeptical paradox," and then constructing the "skeptical solution" to it, Kripke first begins to stitch together his Kripkenstein.

Similarly, the "community view" of meaning that Kripke poses as the solution to the skeptical problem is not Wittgenstein's view at all. By contrast, Wittgenstein says frequently that the kind of agreement that is necessary for "following a rule" is not explicit agreement between the members of a community. It is not agreement "in opinions" or beliefs about what it is to follow a rule, or even in what the majority of members of the community think or take to be the case. To such a notion, Wittgenstein responds:

"So you are saying that human agreement decides what is true and what is false?"-It is what human beings say that is true and false; and they agree in the language that they use. That is not agreement in opinions but in form of life (PI, para. 241).

Agreement in "the language that they use" Wittgenstein clarifies, is agreement at the level of practices of language use. Agreement in form of life is even more basic (more on this below). Social practices (such as language use) are instituted socially. They thus provide the practical context within which any particular application of a rule (whether the meaning of a word or claim, or whether it is true or false) is correct or incorrect. This is the sense in which the meaning and truth of semantic claims (semantics) depends upon and indeed presuppose pragmatics. In the case in question, this means that linguistic claims and particular uses of language are possible, and presuppose practices of language use. It is the normative proprieties of these practices (and not simply "regularities" of use exhibited by and agreed to by the community) that enable claims about truth and meaning, but also constrain and hold accountable specific uses of those claims, as well as the content of those claims.

Rules do not apply themselves. They are able to determine correctness as that which a practitioner ought to follow (and, indeed, are rules at all) only in the context of practices of rule following. Thus, as Wittgenstein says:

And hence also 'obeying a rule' is a practice. And to think one is obeying a rule is not to obey a rule. Hence it is not possible to obey a rule "privately": otherwise thinking one was obeying a rule would be the same thing as obeying it (PI, 202).

According to the "reductive social regularity account" (a more specific term for Kripkenstein's "community view" or "community regularity view"), to follow a rule correctly means following in accord with what the community (or a majority of its members) explicitly agrees to. By contrast, in the context of instituted practices of rule following there is, so Wittgenstein claims in the second half of PI

\footnotetext{
${ }^{51}$ Wittgenstein's repudiation of interpretation in itself appears a few paragraphs prior, in Para 198, where Wittgenstein writes, "[A]ny interpretation still hangs in the air along with what it interprets, and cannot give it any support. Interpretations by themselves do not determine meaning."
} 
201, a way of "grasping a rule which is not an interpretation, but which is exhibited in what we call 'obeying the rule' and 'going against it' in actual cases."

What Wittgenstein actually articulates as a response to his imagined interlocutor in PI 202 and elsewhere differs markedly from Kripkenstein's claim that the regularity to which a community explicitly agrees is what determines the meaning of a claim or word. It also challenges Kripke's claim that the reactions of the community members provide the criterion by which a word or claim is determined to have meaning (or be meaningless) and be correct (or incorrect). For the background practices of rule following entail that whatever the majority of some community says a term or assertion means, they may be wrong. Once instituted, the normative role of a word in a language (while subject to inflections depending upon how it is used in particular instances, by whom, and contextual specifics such as a speaker's collateral commitments) acquires an objective status that is nonetheless relatively established. The practice does not causally determine meaning in successive uses of the word (as if the norms of the practice were "rails laid out to infinity" that Wittgenstein abjures in PI 218). But the normative institution of linguistic practices means that the meaning of a word is not indeterminate either. We might describe it as "under-determined" in the sense that it is flexible vis-à-vis particular uses in specific contexts and circumstances. Novel applications are enabled through the flexibility of the norms that constitute the practice. But further applications are constrained by those norms as well. Thus, the meaning of a word or phrase is not indeterminate. The instituted character of background social practices means that they are constituted by normative proprieties and extend over time. This enables the proprieties of those practices to stand in judgment over successive particular performances of the practice. It is in this instituted character of the practice that one of the dimensions of objectivity emerges and inheres. Wittgenstein describes the institutional character of the practice as follows:

It is not possible that there should have been only one occasion on which someone obeyed a rule. It is not possible that there should have been only one occasion on which a report was made, an order given or understood; and so on.-To obey a rule, to make a report, to give an order, to play a game of chess, are customs (uses, institutions). To understand a sentence means to understand a language. To understand a language means to be master of a technique (PI, para. 199).

Thus, the social practice provides the normative, practical context within which instances of following a rule (or claims by an individual or group about the correct or incorrect way to follow a rule) are correct or incorrect. In other words, I may well think that I am obeying a rule correctly in my use of the word "tree" in the statement "that is a tree," and yet be wrong about it. At the same time, pace Kripke, a group or community may think that they are following a rule, but, in fact, be wrong about that vis-à-vis the institution of the practice of rule following in which following that rule is instituted. The explicit use upon which a group or community may agree is not necessarily the correct use (that explicit agreement is not the source of the word's meaning). Communal agreement is 
accountable to the norms of the practice in which they participate, as well as how things are with those things about which the practice is directed. ${ }^{52}$

To this point, Knight objects that the objectivity that a social practice generates still presupposes, and is relative to, the community in which it is instituted. ${ }^{53}$ Social practices may be normatively and materially constituted in ways to which any and all practitioners are accountable. However, his objection runs, as products of human social activity, these practices are still "ultimately conventional." Thus, norms, rules, and objectivity are always relative to what a particular community has instituted.

Wittgenstein draws a distinction between explicit consensus (e.g. Kripkenstein's regularity of community agreement) and the "consensus" or congruity in social practices that make explicit agreement possible in the first place. Both these instituted practices, and the normative proprieties constitutive of them (sometimes explicated as rules) have an objective status. They "stand in judgment over" (i.e. normatively constrain, even as they enable) any particular performance or enactment of a practice. They even stand in judgment over the communal consensus about it, and thus, however far back one pushes the notion of objectivity, normativity is generated by social practices. This is still "conventional," but in the sense that human claims (in all their objectivity) always and already presuppose and depend upon human social practices. For anywhere there are human claims, there are human social practices of concept and language use. ${ }^{54}$

When it comes to explaining the meaning of words, Wittgenstein says, for instance:

For a large class of cases — though not for all-in which we employ the word "meaning" it can be explained thus: the meaning of a word is its use in the language. And the meaning of a name is sometimes explained by pointing to its bearer (PI, para. 43).

Notice here that "meaning" is not indexed to the use agreed upon by the community (or what a majority of its members agree to) as a criterion of correctness. In many

\footnotetext{
${ }^{52}$ Of course social practices change over time, and no two repeated performances of the practices are exactly identical. But the diachronic dimension of practices also constitutes a vector of practical accountability for practitioners, and what I might call "non-identical repetition" of performances of the practice. Wittgenstein addresses the extension of the normative proprieties of the practice over time, suggesting that any particular instance is accountable to the trajectory of antecedent (and ostensively future) performances of the practice that have adequately met its normative proprieties. "'But I don't mean that what I do now (in grasping a sense) determines the future use causally and as a matter of experience, but that in a queer way, the use itself is in some sense present.'-But of course it is, 'in some sense'! Really the only thing wrong with what you say is in the expression 'in a queer way'. The rest is all right; and the sentence only seems queer when one imagines a different languagegame for it from the one in which we actually use it" (PI, 195). As Hilary Putnam points out, this is another pivotal passage that Kripke misreads, again mistaking the interlocutor's claim for one that Wittgenstein himself embraces (i.e. including the phrase "in a queer way"). Putnam takes Kripke to task for his reading of Wittgenstein in Hilary Putnam, "Kripkean Realism and Wittgenstein's Realism," in Anat Biletzki, ed., The Story of Analytic Philosophy (New York: Routledge, 2002), 241-52.

${ }^{53}$ Knight, "Wittgenstein's Web," 357-58.

${ }^{54}$ Surely, we can hypothesize about what the objective states of affairs in the world would have been like if humans (and thus human social practices and conventions) had never existed or evolved. However, our doing this is always and already on the basis of our conceptual and linguistic social practices and conventions. But this only pinpoints the objectivity of human social practices, thus introducing another cross-contextual feature of accountability and comparability. So, the very conceptualization of the non-linguistic natural kinds of the world over against human normative conceptual netting cast over it is already to have misread Wittgenstein.
} 
cases (though, again, not all of them) particular uses of a word are accountable to that word's role in the language, which, of course, is both enabled and constrained by the practices of language use. And thus, someone deciding to rename a baseball an "engine block" is accountable to more than a particular cohort of self-baptized "engineblock players" (on Knight's example, a group of people he might assemble who agree with him to call the game baseball "engineblock" ${ }^{15}$ ) if they are to pass that community's examination for employing the correct meaning of that word. On Wittgenstein's account, in fact, the claims of that "community" are accountable to the normative proprieties of the up and running practice of language-use from which its languages emerge. And so the instituted social practices enable speakers to address Knight and his merry band of would-be "engine block" players and perhaps chuckle at the peculiarity of philosophers, but eventually to say-"that is a baseball" -and of course, be correct about that. How would they know that? Perhaps they would point to the baseball and say "but look, it is a baseball." If pressed as to how they could know that, they might reply, "I have learnt to speak English."

It is possible that in some different culture, a game had evolved that turned out to be identical to baseball, but had entirely different words for its name and each of its features. That game would still be subject to the objective constraints of linguistic social practices and the objective features of the respective games. Any linguistic differences would be adjudicated between the two cultures on the basis of translation. The "conventional" divergence in the names and words used is possible only against a background of more extensive agreement, including the physical, material, and extensional features of a shared world. It is of "greatest importance," Wittgenstein quips, "that a conflict hardly ever arises between persons about whether the color of this object is the same as the color of that; the length of this rod the same as the length of that, etc." ${ }^{57}$ Elsewhere he makes the point more expansively. "The common behavior of mankind [sic] is the system of reference by means of which we interpret an unknown language" $\left(P I\right.$, para. 206). ${ }^{58}$

\footnotetext{
${ }^{55}$ Knight, “Wittgenstein's Web," 353.

56 "How do I know that this color is red? -It would be an answer to say: 'I have learnt English." (PI, 381). For a particularly lucid repudiation of the conventionalist implications of Kripke's Wittgenstein, see Barry Stroud, "Wittgenstein on Meaning, Understanding, and Community" (1990), in Meaning, Understanding, and Practice: Philosophical Essays (Oxford: Oxford University Press, 2003), 80-94 (esp. 92-3).

${ }^{57}$ Ludwig Wittgenstein, Remarks on the Foundation of Mathematics, G. H. von Wright, R. Rhees, G. E. M. Anscombe, eds., G. E. M. Anscombe, trans. (Oxford: Basil Blackwell, 1956), 323.

${ }^{58}$ On this point (and how Kripke's account diverges from it), Robert Brandom helpfully explicates Wittgenstein. On one hand, certain types of "conventional" practices presuppose features of the world that shape and constrain those practices (e.g. practices of measurement presuppose "rigidity, spatial invariance under transportation, and temporal constancy of measuring rods, interpersonal comparability of measurements, the functional equivalence of various means of measuring the same length, the irrelevance of the results of such contextual features as whether the object measured is sacred or profane, to be used in sport or commerce, and so on"). He continues: "There are three levels at which performances can be discussed: a level of norms explicit in rules and reasons, a level of norms implicit in practice, and a level of matter-of-factual regularities, individual and communal. To say that various claims made at the third level state necessary conditions for the applicability of vocabulary of the sort employed at the first two is not to make a reductive claim. The social regularity view [e.g. Kripke and Wright] conflates the second and the third levels, and so misunderstands Wittgenstein's remarks about the significance of matter-of-factual regularities, by taking them to involve commitment to the possibility of a reduction of the normative to the dispositional [e.g. the reductive social regularity account]." Robert Brandom, Making It Explicit (Cambridge, MA: Harvard University Press, 1994), 46.
} 
Thus, whether through translational calibration (e.g. "grun" in German means green), or within a single language, words and claims are subject to empirical and extensional assessment. For linguistic practices are bound up with the world. And again, as they emerge from the institutions and practices of language use, the meanings and roles of words and claims stand in judgment over particular uses of them, and thus over particular instances of linguistic practices. As Wittgenstein suggests in the PI, linguistic practices are not a "social-practical" conventionalist web of meaning cast over-and thus standing between- natural kinds. When words mean and refer, they do so directly. In referring, words touch directly and immediately with the things they are bound up with. So Wittgenstein:

When we say, and mean, that such-and-such is the case we-and our meaningdo not stop anywhere short of the fact; but we mean: this-is-so (PI, para. 95).

On this account "meaning" is not a ghostly intermediary that bridges a gap between social practices and the "things in themselves" that they are about. Language users are not constantly interpreting the "stuff" of the world as something with each assertion they make. Within the context of social practices, to take an example of Wittgenstein's (PI, para. 198), signposts are not "normatively inert" stuff standing idly by, waiting to have meaning conferred upon them by discrete acts of interpretation. Within a context in which signpost following is an instituted social practice, the signpost just is a signpost. As such, it speaks to those acculturated into the practices of signpost following. Thus, it is direct (immediate, non-inferential). In other words, the conceptual articulated-ness of a particular signpost grasps those who know how to follow signposts.

Herein lies the difference between understanding and interpretation. For the former, the normative proprieties of the practice mean that there are correct and incorrect ways to respond to the signpost. For the latter, the idea that to recognize the signpost as signpost is to always already have applied a rule in interpreting it as a signpost falls into the erroneous regulist regress in that one needs to have followed a rule in order to guide one's interpretation of the signpost, and an interpretation of a rule prior to that to guide the interpretation of the interpretation, and on ad infinitum. ${ }^{59}$ Hence, as Wittgenstein describes it, to understand meaning is to just grasp the normative significance of the thing directly-"'Try not to think of understanding as a 'mental' process at all.-For that is the expression which confuses you..." (PI, para. 154). ${ }^{60}$ The institution of conceptual and linguistic practices interweave with

\footnotetext{
${ }^{59}$ For two helpful treatments (both responding to how Kripke's Wittgenstein goes astray on this point), see Charles Taylor, "To Follow a Rule," in Philosophical Arguments (Cambridge, MA: Harvard University Press: 1995), 165-180, and David Finkelstein, Expression and the Inner (Cambridge, MA: Harvard University Press, 2003).

60 "The absent-minded man who at the order 'Right turn!' turns left, and then, clutching his forehead, says 'Oh! right turn' and does a right turn. - What has struck him? An interpretation?" (PI, 506). Barry Stroud helps clarify this point: "We who understand or interpret the words 'Add 2 each time' as they are normally meant in English recognize what rule those words express, but it would be confusion to say that in addition we also understand or recognize what rule that rule expresses. Once we know what rule those words express, just as a person knows what proposition a certain clump of trees expresses, 'there can be no further question of an understanding'; there is nothing left to be understood. 'That really is how it is; when we are thinking, there isn't any interpretation going on.' (PG, 144)." Stroud, "Meaning and Understanding," The Oxford Handbook of Wittgenstein, 304.
} 
empirical features of the way things are, and also constrain as incorrect particular instances of language use (use of a word or claim).

Clearly, the foregoing passages from Wittgenstein's PI differ markedly from what Kripke thinks follows from the assertability conditions of communally agreed upon use-namely, not "that the answer everyone gives to an addition problem is, by definition, the correct one, but rather that platitude that, if everyone agrees upon a certain answer, then no one will feel justified in calling the answer wrong." ${ }^{\prime \prime}$ Or, as Kripke writes further on, "In Wittgenstein's own model. .. if the community all agrees on an answer and persists in its views, no one can correct it...[I]f the corrector were outside the community, on Wittgenstein's view, he has not the 'right' to make any correction." 62 But here Kripke diverges again rather starkly from what Wittgenstein writes in the PI. For, as Wittgenstein makes clear, the normative proprieties of social practices provide grounds to correct an instance or performance of a practice-even one agreed to by all (or a majority) of the community in question. ${ }^{63}$

By now it should be clear that the Kripkensteinian account of the private language argument is also highly idiosyncratic. ${ }^{64}$ Kripke's claim about the "impossibility of private language emerges as a corollary of [Wittgenstein's] sceptical solution of his own paradox," not from the text of the PI. ${ }^{65}$ Because the condition for the possibility of meaning depends upon community agreement, the possibility of language is, for Kripke's Wittgenstein, "inapplicable to a single person considered in isolation."66

As Wittgenstein investigates this matter, by contrast, the "private language" deemed impossible does not refer to a potential language user making up his or her own language in isolation from a community of fellow language-users (pace the Kripkensteinian portrayal). In the actual text of the PI, Wittgenstein characterizes "private language" as applicable only to the private, immediate inner sensations of the inventor of that language. As such, a private language is putatively impossible for any other language speaker to understand (and, by implication, to translate). It "describes my inner experiences and which only myself can understand" and is "for [the inventor's] private use" (PI, para. 256). Further, as Wittgenstein describes, "the words of this language are to refer to what can only be known to the speaker; to his

\footnotetext{
${ }^{61}$ Kripke, Wittgenstein on Rules and Private Language, 112.

${ }^{62}$ Ibid., 143

${ }^{63}$ Recall here Wittgenstein's example of the wood sellers (Remarks on the Foundations of Mathematics, 94). The example portrays the possibility for some community to persist in shunning correction or persuasion regarding their inconsistency in the way they use the terms "more of" and "less than" in measuring amounts of wood. This appears to prompt the outsider to leave them to their own "system" as one possible result. And yet, far from asserting relativism or incommensurability about the meaning of those terms, Wittgenstein points to the possibility of some person external to a community understanding the community's practices, and then working at length to correct and persuade its members of the inconsistencies in their uses of these phrases. And Wittgenstein suggests that the outsider may well be successful at that. In other words, these tasks are by no means impossible for the outsider "by right" (pace Kripke). Moreover, Wittgenstein's likening the group's refusal to be corrected on this point to the "wise men of Gotham" alludes to the possibility (perhaps the likelihood) of their having collateral reasons for their persistence in their refusal to be corrected that are, ostensibly, understandable and, with reference to their own circumstances, perhaps even wise.

${ }^{64}$ As Kripke himself acknowledges, Wittgenstein on Rules and Private Language, 113. For a more extensive treatment of the character of Kripke's divergence from Wittgenstein on this point (and the difficulties it generates for Kripke's account), see Warren Goldfarb, "Kripke on Wittgenstein on Rules," The Journal of Philosophy 82, no. 9 (September 1985): 471-88.

65 Ibid., 68.

${ }^{66}$ Ibid., 79.
} 
immediate, private sensations. So another person cannot understand the language" (PI, para. 243). By contrast, on the Kripkensteinian reading, these characterizations do not reflect what Wittgenstein has in mind with the "private language" argument. For, again, on Kripke's reading, the notion of a "private language" must be indexed to "the skeptical problem and its solution."

This does not pertain (again, pace Kripkenstein) to the putative impossibility of meaningful language evolved by a solitary person (i.e. a language constituted apart from a community of fellow-users of that language). Here one might think of the speech devised by Robinson Crusoe, had he been stranded as an infant on a desert island (and thus a solitary language user). Such a solitary language inventor could very well come to be understood in other languages through processes of translation. ${ }^{68}$ Rather, Wittgenstein's private language argument casts suspicion on the possibility of a language so sealed-off in interior privacy and of its own kind (perhaps, as such, "incommensurable" with all other languages) as to be intrinsically unintelligible to other language-users. It is, thus, not translatable by any other language speakers. It is essentially and exhaustively immediate and internal to its inventor. However, to recognize something as a language at all (however internal, private, and discrete) already presupposes a shared background of linguistic practices, and thus, commensurability with other languages. This makes it possible in principle for anyone who recognizes something as a language to understand and to translate it.

Suppose that a solitary person invents a language that implicates him or her in linguistic practice (i.e. the rule following practices which are fundamental to our language game). The rules of that language will not be whatever he/she takes them to be (or says they are) at any given point. For Wittgenstein, language-use is predicated upon the practices of rule following. This means that even the solitary inventor of the language is accountable to the normative constraints that make the language a language at all. To invent a language is to bind oneself by the norms of the language that one has invented. This, again, reflects the authority structure one finds in Wittgenstein: when I bind myself by a rule, the content of the rule by which I bind myself flies free of any sense I might have or any claim I might make that I have followed the rule. ${ }^{69}$ For otherwise, Wittgenstein points out, "to think that one was following a rule would be following the rule." But, recall, Wittgenstein firmly rejects the latter claim, saying the opposite: "One would like to say: whatever is going to seem right to me is right. And that only means that here we can't talk about "right'" (PI, para. 258). Because following a rule is a practice whose norms fly free of what any practitioner (even the solitary inventor of a language) takes him or herself to

\footnotetext{
${ }^{67}$ Ibid. Again, what Kripke identifies as PI 138-242, and characterizes as "the primary concern" of his essay.

${ }^{68}$ Kripke attempts to anticipate this objection by characterizing any recognition of such a Crusoe figure as automatically "taking him into our community" and to have always and already removed him from true isolation, and relocated him into the context of our "assertability conditions" (110). Baker and Hacker respond by appealing to the distinction between background practices and agreement in judgments/responses. "To be sure, in order to grasp [Crusoe's rules] we must understand what counts, in Crusoe's practice, as following the rules. And that must be evident in Crusoe's activities. But that is not the same as checking to see whether his responses agree with ours, let alone a matter of 'taking him into our community"." See their Skepticism, Rules, and Language,(Oxford: Basil Blackwell, 1984), 40-41.

${ }^{69}$ This is the account of conceptual authority that I use (borrowing from Brandom's articulation of it) - the two-ply effectiveness of force and content together. See Jason Springs, Toward a Generous Orthodoxy, 158-65.
} 
have done, to think one is obeying a rule is not necessarily to obey it. Likewise, to claim that whatever one does or thinks in one's purely "private" realm, at any given moment, instantiates and follows a rule, is not to follow a rule. And this is the reason it is not possible to obey a rule "privately" in the sense Wittgenstein articulates in the PI.

Thus, to be a language at all is to be intrinsically other than "private" (i.e. "language which describes my inner experiences and which only myself can understand" (PI, para. 256), and is "for [my] private use"). Rather, it is to be intrinsically understandable, follow-able, and translatable by other linguistic practitioners. It is a practice to which any rule follower is accountable (regardless of what he or she thinks or claims to be the case). In sum, Kripke departs rather drastically from the actual text of the PI, treating "Wittgensteinian themes" in idiosyncratic ways (as Kripke acknowledges). It is not an actual reading of what Wittgenstein wrote.

Frei acknowledged first reading Wittgenstein's PI as early as 1964. Even so, his explicit engagements with Wittgenstein are relatively spare in the overall scheme of his corpus. Nor is there any evidence or indication in any of Frei's writings or papers that he read Kripke's treatment of Wittgenstein. Some of Wittgenstein's actual writings did provide a resource Frei drew upon for his Christological purposes. On one hand, Frei's references to Wittgenstein reflect his use of ad hoc apologetics (described in Part I above). At the same time, as I demonstrate in Part III below, Frei's passing engagements with Wittgenstein are not Kripkensteinian in character. Knight's treatment of Frei, by contrast, is structurally inflected by the mistaken assumption that Frei's commitments are fundamentally Kripkensteinian. Indeed, it seems that the Kripkensteinian "community regularity view" of meaning serves as a pre-fixed frame with which Knight tailors his characterization of Frei's work. I fear this ultimately leaves Knight without resources to understand the ways that Frei actually appropriated Wittgenstein's thinking.

\section{Why Not Soames?}

Scott Soames' treatment of Wittgenstein is less well-known than Kripke's. Here, I will address only some features of Soames' account that contribute to Knight's case against Frei. As Soames characterizes it, Wittgenstein's later work formulates a "conventionalist" account of meaning. This means that words and sentences do not derive their meaning by virtue of referring to, describing, or relating in any way to objects in the world; it rejects any account according to which the meaning of a sentence is "the potential fact or state of the world that it represents." ${ }^{\prime 70}$ Words and sentences derive their meaning purely from the agreement expressed in their use by a group of speakers in some context. Thus, meaningful language is possible only if there is what Soames calls "an agreed upon pattern of use of the expression to which language users conform that allows it to play a useful and intelligible role in their lives....[A]ny expression for which there are socially useful agreed-upon conditions of correct application qualifies as meaningful." ${ }^{\prime 1}$ Thus Soames has characterized Wittgenstein as offering a reductionist account of "meaning as use." That is, the meaning of words reduces to the conformity of its use with the use that the respective community of users (or a majority of its members) agrees to. Hence, the meaning of a word or sentence really is a kind of warranted assertability regarding meaning

\footnotetext{
${ }^{70}$ Ibid., xx.

${ }^{71}$ Soames, Philosophical Analysis, II, xxi.
} 
("legitimate assertability" Knight says)—the meaning that your peers agree to (explicitly or in the regularities of their behavior). The correctness of any application of a word is determined by whether or not that application is in "conformity with community use." ${ }^{\prime 72}$

Soames' account replicates at least five of Kripkenstein's most central characterizations of Wittgenstein in Wittgenstein on Rules and Private Language. Like Kripke, Soames (1) claims that Wittgenstein's consideration of rule-following is "the centre of gravity"73 of the Philosophical Investigations; and (2) ascribes to Wittgenstein the requirement of agreed to uses among the members of a community as the means by which words can be said to have a meaning (thus forwarding the "community view" of Wittgenstein for which Kripkenstein is an exemplar). In other words, as Soames reconstructs Wittgenstein "conformity with community use provides standards of correctness for an individual's use of many of our most basic terms. ${ }^{74}$ In order for someone's use of a term (elementary or otherwise) to have meaning, that use must meet with the agreement of the other members of the community of language users. ${ }^{75}$

What naturally follows from this is that (3) Soames replicates the Kripkensteinian "private language argument" as challenging the possibility of a "solitary language user." This is because a solitary person would not be subject to the agreed upon uses of the (majority of) fellow users of the language. Further, (4) Soames ascribes to Wittgenstein the position that at the level of justification at which reasons give out, all a member of some community has to rely upon is instinct: one "applies a word instinctively" - "We do not follow 'internal rules' but our inclinations." 76

Like Kripkenstein, Soames elides Wittgenstein's claims that the nature and character of the agreement is at the level of background practices and practical contexts of linguistic use (the constitutive congruities and material constraints of language-use). He thus overlooks how these background levels of agreement then make semantic claims about meaning and truth (whether they agree or disagree) possible, and language-use generally (which generates the possibility of translation even for a solitary user/inventor of a language). This subjects Soames' portrayal of Wittgenstein to the same responses that Kripke inspired. As Michael Beaney puts it, "What is important is that there exists a practice of linguistic use in which there could be agreement in judgments."

(5) Like Kripke, Soames admits that the account of Wittgenstein he sets forth deviates from anything Wittgenstein says in the $P I$ and results in a portrayal of Wittgenstein that Wittgenstein himself would surely reject. ${ }^{77}$ In fact, Soames'

${ }^{72}$ Ibid., 34 n 2; see also 17, 25, 32, 34, 38-40, 50, 52.

73 Ibid., 31

74 Ibid., 34, n 2.

${ }^{75}$ See, e.g., Ibid., $17,25,32,34,38-40,50,52$.

${ }^{76}$ Ibid., 33-4.

${ }^{77}$ Knight acknowledges Soames' admission that Wittgenstein would surely reject his characterization of Wittgenstein's views. However, Knight then brushes past this concern, saying that Wittgenstein's rejection of Soames' treatment of his work would be rooted in Wittgenstein's "anti-theoretical sentiment" (Liberalism versus Postliberalism, 146). This bias would then determine Wittgenstein's response to Soames' effort to transmute Wittgenstein's PI into a theory (or "toward a theory"). Again, here Knight conflates an unsystematic approach (i.e. Wittgenstein's effort to avoid asserting and defending philosophical theses) to philosophical reflection with "antitheoretical bias." In my view, Wittgenstein would resist Soames' characterization of his views for the same reasons that many Wittgenstein scholars have as well-namely, because Soames's characterizations deviate so greatly from what Wittgenstein actually wrote. In a lucid 
portrayal of "Wittgenstein" replicates what are, arguably, the most distinctive features of Kripkenstein. Soames adds to this a claim that Wittgenstein's "antitheoretical bias" is indicative of "ordinary language philosophy" generally. He then criticizes Wittgenstein's PI as flawed at its core. That this Kripkensteinian account becomes the basis for Soames' repudiation of Wittgenstein's theory of meaning is central to Knight's use of Soames's account. In what follows, I briefly examine how the above picture of Kripkenstein orients and colors Knight's characterization of Frei and subsequent criticisms.

\section{Why Not Knight?}

Kripke's portrayal of Wittgenstein is, as Kripke himself acknowledges, broadly (if intentionally) inexact. It is in replicating Kripke's central claims as if they were accurate that Soames's allegedly devastating criticisms of Wittgenstein become misdirected. Hence, Knight's treatment of Frei encounters difficulties not merely at the theological level (more on this in Part III below). It also encounters difficulties because the account of Wittgenstein with which Knight characterizes Frei's theology, and then on that basis declares it a dead end, is faulty.

Knight acknowledges the general controversies surrounding Kripke's account. He proposes to take the "uncontroversial" portion while leaving the controversies aside. $^{78}$ But is this feasible? In fact, the three portions of Kripke's account are interlinked. This is Kripke's claim, at least. ${ }^{79}$ And Knight indicates that the Kripkensteinian understanding of the "private language argument" emerges as a corollary to, and is dependent upon, the skeptical paradox and skeptical solution:

[T] hese specifiable circumstances [in which an assertion could be determined to be "legitimately assertable"], and the role that the assertion plays, can only be specified with reference to a community. They don't make sense as applied to a single individual considered in isolation. This is because to ask about roles that an assertion plays and the conditions under which it can play that role is to ask about what rule we follow in asserting it. But Wittgenstein argues that, considering a person in isolation, there is no fact about her in virtue of which we can tell in a given case whether she is following a rule or not. Thus, it is not possible to obey a rule privately. ${ }^{80}$

and highly charitable review essay, Michael Kremer points out that, in his treatment of the later Wittgenstein, "Soames neglects a large scholarly controversy, which has brought into question many claims around which he builds his story [i.e. the controversy embroiling Kripke's Wittgenstein]." Kremer continues, "Curiously, while Soames often supplies copious quotations from the figures he discusses, his summary of Wittgenstein's general views on meaning and understanding (Vol. 2, 33-44) is not based on a single piece of textual evidence." With remarkable clarity and charity, Kremer goes on to take specific issue with Soames' treatment of Russell, Wittgenstein, Ryle, and Kripke. Michael Kremer, "Review of Scott Soames' (Book 1) Philosophical Analysis in the Twentieth Century, Vol. 1: The Dawn of Analysis; (Book 2) Philosophical Analysis in the Twentieth Century, vol. 2: The Age of Meaning," Notre Dame Philosophical Reviews (September 19, 2005): https://ndpr.nd.edu/news/24868-book-1-philosophical-analysis-in-thetwentieth-century-vol-1-the-dawn-of-analysis-book-2-philosophical-analysis-in-the-twentieth-century-vol-2the-age-of-meaning/ (visited Oct. 8, 2015).

${ }^{78}$ Knight, Liberalism versus Postliberalism, 147, n 19.

${ }^{79}$ Kripke, Wittgenstein on Rules and Private Language, 68.

${ }^{80}$ Knight, Liberalism versus Postliberalism, 147. 
The position that Knight here ascribes to Wittgenstein actually restates the Kripkensteinian account of private language and the skeptical paradox. What is "legitimately assertable" as a meaningful assertion (or is warranted as assertable, i.e. warranted assertability regarding meaning) is specified by agreement with the fellow-members of the community.

Now, Knight has acknowledged that he follows Kripke's account of Wittgenstein. He acknowledges, further, that Kripke's "skeptical" interpretation is controversial. He purports to take only those portions of the account that are not controversial. But at this point it is not clear precisely what Knight understands Kripke's controversial "skeptical interpretation" to be. For Knight takes the account of Wittgenstein he advances here to be not only comfortably removed from those controversies, but the "dominant" and "best" understanding of Wittgenstein. ${ }^{81}$ And yet, though he restates Kripkenstein's position with great fidelity, Knight takes himself to be accurately representing what "Wittgenstein argues" in the PI. ${ }^{82}$ However, Wittgenstein argued none of these things. It is, rather, Kripkenstein who argues that, "as is well known, Wittgenstein rejects "private language" (i.e. the impossibility of language for "a person in isolation" from an actual community of fellow language-users, and about whom "there is no fact. . in virtue of which we can tell in a given case whether she is following a rule or not"). ${ }^{83}$ Contrary to what he takes himself to be doing, it appears that Knight has swallowed the Kripkensteinian account hook, line, and sinker. And this, we will see below, creates a structural difficulty in his analysis of Frei.

\section{Wittgenstein and Frei on the Role of Reference in Meaning}

Knight follows Soames in claiming, "In the Investigations Wittgenstein rejects the notion that the meaning of a sentence (atomic or otherwise) consists in the possible fact of the state of affairs that it describes." 84 As Knight puts the point, on this account "language cannot acquire its meaning from its ability to describe or refer to some part or aspect of the world. Instead, language gets its meaning from the roles(s) it plays in an agreed pattern of usage that structures some significant and intelligible part of our lives." 85 Further, "even the parts that do have referential or descriptive functions are not completely referential or descriptive." And yet, referring is one of the things people do when they use language and engage in actions. Knight (following Soames) casts this as an either/or-as though the agreed upon practices of some community (some form of life) cannot be accountable to the way things are in the world. Again, what Wittgenstein says is:

When we say, and mean, that such-and-such is the case we-and our meaningdo not stop anywhere short of the fact (PI, para. 95).

\footnotetext{
${ }^{81}$ Knight, “Wittgenstein's Web,", 339.

${ }^{82}$ Ibid.

${ }^{83}$ The latter point, which Knight ascribes to Wittgenstein, is derived by Kripke from his "skeptical interpretation." See Kripke, Wittgenstein on Rules and Private Language, 272-3.

${ }^{84}$ Knight, Liberalism versus Postliberalism, 146.

${ }^{85}$ Ibid, 142.
} 
Likewise, Knight makes much of the fact that Wittgenstein comes back to a "form of life." He takes this to mean that a form of life is just "brute" for Wittgenstein. This makes Wittgenstein (and so Frei) subject to Soames's charge of Kripkensteinian "conventionalism." Let us revisit this just for a moment. Knight understands "form of life" in terms of Kripke's and Soames' understanding of agreement at the level of "following a rule." He writes:

[T] he rules on which we agree, the way in which they interact with our practices, constitute our form of life. For Wittgenstein, our form of life is just a given; it is a brute fact that must be simply accepted, it is in the context of our form of life that the agreement of the community is enacted. ${ }^{86}$

Notice the role of rules in this description. The "form of life" is constituted by the community's agreement upon certain rules, and the interaction of those rules with the community's practices. This configuration is "brute." But where does Wittgenstein say that "the rules on which we agree...constitute our form of life?" Knight offers no textual citation. What Wittgenstein says is that "following a rule is FUNDAMENTAL to our language game," and that "following a rule is a practice. And to think that I am following a rule does not mean that I am following a rule." 87 But the community's agreement upon the rules does not itself constitute a form of life. Rather, for there to be rules, and for those rules to be binding and to bind action, practices of rule following must already up and running, in all the material and empirical constraints they presuppose. The former is contingent upon the latter. And this point is determinative for how Wittgenstein's "forms of life" are understood. To consider what Wittgenstein writes, and contextualize these claims within his later writings: "What has to be accepted, the given, is - so one could say - forms of life" (PI, para. 226). Or, as Wittgenstein puts it in Remarks on the Philosophy of Psychology, Vol. I, §630, [very general] "facts of living." What might it mean to think of "forms of life" in terms of very general facts of living? ${ }^{88}$

Wittgenstein indicates that the linguistic practices on which he focuses so much attention are not unique or categorically distinct from, but rather are bound with, the basic non-linguistic features of human beings. For instance, linguistic activities such as commanding, questioning, recounting, chatting, among others, "are as much a part of our natural history as walking, eating, drinking, playing." The latter do not explicitly involve ("do not depend on") language per se (PI, para. 25). For Wittgenstein, there is nothing intrinsically impossible about ostensive reference understood as bound up with our practices of communication and meaning.

\footnotetext{
${ }^{86}$ Ibid., 148.

${ }^{87}$ See the helpful exposition of Fergus Kerr, Theology After Wittgenstein (Oxford: Blackwell, 1986), 110. The Wittgenstein quotation is from Remarks on the Foundations of Mathematics G. H. von Wright, R. Rhees, G. E. M. Anscombe, eds., G. E. M. Anscombe, trans., revised edition (Oxford: Basil Blackwell, 1978), (VI, 28) and PI, 202. Emphasis in original.

${ }^{88}$ As Hilary Putnam points out, on occasion, Wittgenstein does say things that may sound like they support the kind of relativism and non-normativity that Kripke ascribes to the concept of "form of life" (e.g. PI, Para 559). Putnam demonstrates how such a reading de-contextualizes these sayings. See, for instance, Hilary Putnam, "Wittgenstein on Reference and Relativism," in Renewing Philosophy (Cambridge, MA: Harvard University Press, 1992), 158-79 (esp. 168-79).
} 
Wittgenstein emphatically denies that ostensive reference is the entry level to understanding and explaining meaning. "Children do not learn that books exist, that armchairs exist, etc. etc.- they learn to fetch books, sit in armchairs, etc. etc." (OC 476). Children learn language through the practice of matching words with the items (or images of the items) to which those words refer, and thus come gradually onto the scene of language acquisition. Such learning comes only after much accompaniment, training and ever-so-gradual participation in the practices of toing and froing with their surroundings. This occurs through engagement with, and eventual imitation of, those who live and speak with them. It occurs through socialization, and eventual explicit instruction by caregivers over time. It comes after much sitting in chairs, crawling on floors, swinging in swings, sleeping in cradles, drinking water, eating food, cooing, and babbling that provokes responses by caregivers, and so forth. Playing the "matching game" of word and referent is possible only for those who already have sufficient practical knowledge ("know how") of their environs and incipient grasp of social practices. Such emergent "know how" includes the practical abilities by which they distinguish between-and so vary their interactions withthis and that, here and there, and so forth. This incipient "know how" comes far prior to the "know-that" of matching word to referent.

Once rudimentary concept use and communicative exchange are up and running as practices, then explaining and clarifying meaning-and holding each other accountable-through referring ostensively emerges from them. On this view of acculturation, training, and socialization into linguistic practices, customs, and institutions, linguistic practice is normative all the way down. Any or all of the participants are accountable to the normative constraints of the practice. The community is accountable to the normative and empirical constraints of the practice as well.

On the Kripkensteinian reading, by contrast, the community is just "given" in a non-normative sense. Individuals are correct by going in accord with- or incorrect by going against - agreed upon community consensus. Participation in that agreement (by acting in accord with the agreed upon uses of the group) occurs ultimately, as Soames says, instinctively, or dispositionally. The deepest level of justification for this agreement is that this is how one has been trained by virtue of one's participation in the community (or majority) consensus, and again, that "this is what we do." But, on this account, the "brute" and "given" character of the agreement of the community itself is neither correct nor incorrect about what its communal agreements determine to be the case- "the community just goes." As Knight puts it, "the form of life is just given; it is a brute fact that must simply be accepted, and ...[in which] agreement of the community is enacted." ${ }^{89}$

\footnotetext{
${ }^{89}$ Ibid. Readers of Robert Brandom will recognize this as exemplifying what he characterizes as an IWe conception of authority and normativity, and a reading of Wittgenstein that he repudiates as a "reductive social regularity account of the practices in which norms are implicit" (Brandom, Making It Explicit, 46). We can also see exemplified here the way that "communal agreement" is portrayed as the criterion for correctness and how it personifies the community as though it were, itself, an individual actor. "Thus to pick one page almost at random, Kripke talks about 'the community's accepting' conditionals codifying relations between attributions of intentional states and commitments to act, what 'the community regards as right,' what 'the community endorses,' and so on" (Brandom, Making It Explicit, 38). In my view, Knight imputes precisely such a Kripkensteinian account of communal authority to Frei. As Knight alleges, for Frei, "Christians have a distinctive form of life, and the meanings of their religious language, of theological language, and of the biblical texts, all derive from the role such language plays in their form of life." Moreover, the meaning of that language comes "only from the use-the agreed
} 
It is this understanding of Wittgenstein that Knight attributes to Frei, which he then critiques, and concludes that Frei's project is a dead end. Knight insists that, for Wittgenstein, a form of life is just "brute." Knight then alleges that Frei's construal of the church as a language-forming form of life has precisely this Kripkensteinian sense. The Christian community is just "brute." As such, it is the "ultimate arbiter" over the meaning of every scriptural text. Thus, the form of life (here, what it takes its mission to be) is the context in which the members of the community converge upon their agreed upon uses as the source of meaning. Individual members can be out of step with that. But the community itself can be neither correct nor incorrect. The community "just goes" in the sense that whatever the Christian community decides is the literal sense of the scriptural text will be literal sense of the scriptural text. As Knight puts the point, "Thus what makes a particular sense of a biblical text the 'literal' sense is whatever the community's judgment (or the presupposition of certain of its actions) that this particular sense is authoritative ${ }^{\prime \prime 90}$

But portraying Frei as Wittgensteinian in this distinctly Kripkensteinian way is not helpful. For Frei, as for the "real" Wittgenstein, when agreement is at the level of the practices, customs, and institutions, the community can be wrong or right about what it takes to be the case. For what the community determines or takes to be the case in its explicit agreement is accountable to the normative proprieties of the practices, customs, and institutions. But there is an additional level to consider here as well. Social practices are object-directed. This means that human acting and meaning interweave seamlessly with the objects in the world to which our sayings refer. This entails empirical and extensional components of accountability. Once a practitioner has become adept in the practice, she is able to deal non-inferentially (directly, immediately, without need to apply and justify the use of the concept) with the objects to which they refer. In terms of the Scriptural practices that Frei works with, this observational immediacy is analogous to the moment of explicatio. When Frei describes explicatio (observation) as the ground level entry-point into the gospel narratives, he means that, for adept readers and participants in the social practices of reading, consulting, studying scripture, using it in worship, word and sacrament, the stories are directly accessible. In other words, Wittgenstein's account of the social practices of the community entails objectivity.

By contrast, the Kripkensteinian character of Knight's rendering of Frei is evident when he attributes the following positions to Frei:

"[T]he sensus literalis is the way the text has generally been used in the community. It is the sense of the text in its sociolinguistic context-liturgical, pedagogical, polemical, and so on." Like Lindbeck, Frei here cites Wittgenstein as his inspiration for his articulation of this third understanding of the literal sense. In the context of the religious community, the way a text is used in a community just is the teaching of the text that the community considers to be authoritative...Thus what makes a particular sense of a biblical text the "literal" sense is whatever the

use-of the community" (Knight, Liberalism versus Postliberalism, 211). This positions Frei with a far more hermetically demarcated and internally uniform account of the Christian tradition as a (Kripkensteinian) "form of life" than Frei ever held. This also holds for Knight's characterization of the "sensus literalis" as what Knight alleges to be the "criterion" for meaning in that Christian form of life. Again, Fulford is helpful on this point. See Ben Fulford, "Review of Liberalism versus Postliberalism," Journal of Theological Studies 65, no. 1 (2014): 363-67 (here 366).

${ }^{90}$ Knight, Liberalism versus Postliberalism, 208. 
community's judgment (or the presupposition of certain of its actions) that this particular sense is authoritative. And a particular sense will be authoritative in so far as it enables the church to live out its mission....Frei's move to this third understanding reveals his commitment to a Wittgensteinian understanding of meaning. This third understanding of the literal sense gives to the community the role of the ultimate arbiter of the meaning of any and all biblical texts. That meaning is now indexed to the use of the text in the living out of the community's mission. It is here that we can see most clearly the influence of the later Wittgenstein as well as Frei's theological kinship with Lindbeck. ${ }^{91}$

But Frei held no such view that a community's use of a text "just is the teaching of the text that the community considers to be authoritative," a view that would indeed make the community the "ultimate arbiter of the meaning of any and all biblical texts." To the contrary, Frei describes numerous constraints upon the church's engagements with scripture-constraints to which the "agreed use" " $^{92}$ of Christian interpretive communities (what they take the texts to mean, or recognize as authoritative) are accountable. These include, for instance:

1. The grammatical/syntactical and literary-literal features of the text that resist and press back upon reading and interpretation. On Frei's account, sometimes widelyranging disagreements emerged among readers of Christian scripture precisely because the scriptural text "resists" any attempt to exhaustively interpret it. "The text," Frei wrote, "is not inert but exerts a pressure of its own on the inquiring reader..."93 Thus, "there can be no non-residual reading, no complete interpretation" because a "good enough text has the power to resist." For this reason, when claims about the meaning of scripture conflict and inspire controversy, the task of reading and consulting scripture required is not one where the readers take a vote to see whose opinion wins the day. Rather, the task is one of sitting down and holding each other accountable to "the features of the text," as well as what each reader is doing in engaging the text. These are all intimate features the practices of reading, consulting, and understanding scripture. Moreover, readers' understandings and interpretations of these texts are accountable to those features. Of course, non-Christians could hold Christians accountable to the features of scriptural text as well, though they do not endorse its claims as their own.

2. "Historical reference" as a minimal threshold (indeed, ostensibly definitive) constraint upon the community's engagement with scripture, for instance, that the stories of Jesus' of Nazareth life as a historical person and execution have not been ultimately disconfirmed by means of historical investigation (historie). Indeed, what scripture testifies as having happened then and there may have been, for example, fabricated by the disciples. In that case, Frei confessed he would have given up being a Christian. This is a claim that separated Frei from Barth. For Barth, "encounter with the living Christ" made the possibility of historical disconfirmation a non-question. ${ }^{94}$

\footnotetext{
${ }^{91}$ Ibid., 208, 209.

92 Ibid., 211.

${ }^{93}$ Frei, Types, $86-7$.

${ }^{94}$ For expansion of this important difference between Barth and Frei, see Hunsinger, "The Daybreak of the New Creation," 179-80.
} 
3. Three senses in which the stories "mean what they say." These are: a) in their "storied sense," b) as a "fit enactment" of what their authors intended, but also c) with reference to what happened then and there. ${ }^{95}$ As Frei puts it, the name "Jesus refers like any other name" to a person then and there. Moreover, the events portrayed in the gospel accounts of the resurrection must have happened- "more nearly than not"-as they are witnessed to in Christian scripture. ${ }^{96}$ Note that here we see the "signified subject" is an integral piece interwoven with the literaryliteral and grammatical-syntactical constraints, along with reference to use in context. This is crucial, for it means that Frei does not simply hold together what he calls "use in context" along with the normative constraints exerted by the constitutive features of the text and practices of reading and interpretation. Equally important is the text's adequacy for rendering what is claimed to have happened then and there. On this account, he says, the texts "mean what they say, so that their subject is indeed the bodily resurrected Jesus." On this account, "the miracle of the resurrection. .. is [taken to be] a real event....[though] human depiction and conception are [ultimately] inadequate [to depict and account for it]...[T]he literal description is the best that can be offered....Text and reality are adequate, indeed, indispensable to each other but not identical..." And again, he maintains: "[T]he literal account of the text is adequate to the reality of the events by divine grace."197

4. Christian communities' practices of reading and consulting texts are accountable to the Christological norm that emerged from their engagement with their source and norm (e.g. the apostolic witness-a constraint upon what Christian communities take scriptural texts to mean that I treat in Part III below).

${ }^{95}$ I should note that I am traversing all too quickly a complex set of claims regarding the roles of textual and historical reference as constraints in Frei's treatment of the literal sense. For a more extensive discussion, see Jason Springs, Toward a Generous Orthodoxy, Chap. 4, "But Did it Really Happen?". Frei's reliance upon historical reference is best described as an "ad hoc minimalism." The position has been ably explicated and defended in these terms by George Hunsinger, "What Can Evangelicals and Postliberals Learn from Each Other?" in Disruptive Grace (Grand Rapids, MI: Wm. B. Eerdmans Publishing Company, 2000), 338-60 (especially 347-54). Knight acknowledges this discussion, but admits that the concept of dual reference "remains confusing" for him. A slippage occurs in Knight's reading on this point a few lines later, where Knight imputes his own confusion to Frei: it becomes "Frei's confusion" (Liberalism versus Postliberalism, 258). The latter by no means follows from the former. Hunsinger's exposition of Frei's account is, in my judgment (and that of many others), admirably clear and cogent. In my view the discrepancy emerges in virtue of Knight viewing Frei as committed to, and motivated by, a treatment of Wittgenstein that Frei did not hold.

96 "[The believer] would have to affirm that the New Testament authors were right in insisting that it is more nearly correct to think of Jesus as factually raised, bodily if you will, than not to think of him in this manner. (But the qualification 'more nearly ... than not' is important in order to guard against speculative explanations of the resurrection from theories of immortality, possibilities of visionary or auditory experience, possibilities of resuscitating dead bodies, miracle in general, etc." (Frei, Identity, 182). But there is "breathing room" here as well. The accounts of Jesus are not straightforward historical reports. As William Placher put it, "The stories capture through narrative a person's identity. Reading these stories, one learns who Jesus is-that is, one learns both the characteristics of his human life and the fact that that human life was somehow the self-revelation of God. Many of the episodes serve as biographical anecdotes, 'true' if they illustrate his character authentically even though the particular incident they narrate never happened, and the overall shape of the narrative portrays something of Jesus' identity." William C. Placher, Narratives of a Vulnerable God (Louisville, KY: Westminster/John Knox Press, 1994), 92-7 (here 92, 93).

${ }^{97}$ Hans W. Frei, "Of the Resurrection of Christ," Theology E Narrative: Selected Essays, edited by George Hunsinger and William C. Placher (Oxford: Oxford University Press, 1993), 203. Curiously, Knight does not include in his treatment of Frei the important essay in which these claims appear. 
In a nutshell, the question of whether or not the events to which the resurrection account witnesses really happened (or more nearly than not) exerts myriad, and quite definitive, constraints on the interpretive community. This point subverts Carl Henry's claim that, for Frei, the biblical narrative is a self-contained, discrete world that does not refer beyond itself (and, likewise, to what David Tracy and Gary Comstock claimed to be Frei's "pure narrativism"). ${ }^{98}$ Thus, while Frei does refuse (for Christological reasons) a single, formal theory of meaning, it is not correct to say that reference plays no role in what he does say about meaning. It is even less correct to base such an attribution upon his putative rejection of philosophical descriptivist accounts of meaning. ${ }^{99}$

The point in question for Knight's Kripkensteinian portrayal of Frei is the nature and force of communal authority in determining the meaning and significance of the biblical witness. As Mike Higton argues, "precisely by taking a narrative reading as primary rather than an allegorical or purely symbolic one, the Church allowed the Bible to stand over against it as an independent norm which it could not control."100 Notice the characterization of the norm as independent from what the community might have agreed (or agrees) to be the case. Moreover, as an independent norm scripture constrains what the Christian community takes these texts to mean. In other words, the Christian community may collectively think that it is obeying the rule, but not be. The community may be in agreement that it is following the Christological norm, and yet be wrong about that.

But, yet again, we must not pass over Frei's deep concern not merely with the fact that some basic interpretation of the gospel accounts emerged as authoritative, but how and why that interpretation became authoritative in the way that it did. We must ask next, why did the Christian community take the literal sense ${ }^{101}$ as a norm that both carved out broad space for, and stands in judgment over, multifarious readings of scripture and often conflicting claims about the meanings of scriptural passages? Was it a matter of chance that the community found this reading "useful" for what it understood to be its "mission"? ${ }^{102}$ These questions bring us to the second

\footnotetext{
${ }^{98}$ For a helpful treatment of these controversies that highlights the relevance of Frei's Christologically motivated use of ad hoc apologetics, see Jeffrey Stout, "Hans Frei and Anselmian Theology," in Ten Year Commemoration to the Life of Hans Frei (1922-1988), edited by Giorgy Olegovich (New York: Semenenko Foundation, 1999), 24-40. For the charge of pure narrativism, see Gary Comstock, "Truth or Meaning: Ricoeur versus Frei on Biblical Narrative," Journal of Religion 66 no. 2 (April 1986): 117-140; David Tracy, Dialogue with the Other: The Inter-religious Dialogue (Grand Rapids, MI: Wm. B. Eerdmans Publishing Company, 1991), 201-210.

99 "[Y] es, 'Jesus' refers, as does any ordinary name, but 'Jesus Christ' in scriptural witness does not refer ordinarily; or rather, it refers ordinarily only by the miracle of grace. And that means that I do not know the manner in which it refers, only that the ordinary language in which it is cast will miraculously suffice. It is historical reference (to use our cultural category) but it is not historical reference in the ordinary way ... nor of course is it metaphor." Hans W. Frei, "Response to 'Narrative Theology'," Theology and Narrative, 210, 212. Frei's references to "ordinary language" here should not be read as an appeal to "ordinary language philosophy." It is not. His point is to emphasize the orientational role of a miracle of grace in making the ordinary words of scripture adequate as a witness to Jesus Christ.

${ }^{100}$ Mike Higton, "Frei's Christology and Lindbeck's Cultural-Linguistic Theory," Scottish Journal of Theology 50, no. 1 (1997): 83-95; at 92.

${ }^{101}$ This is Frei's compound conception of the literal sense as "not only as use-in-context but as unity of grammatical/syntactical sense and signified subject ["literary-literal" or "storied sense" and-more nearly factual than not- "the bodily resurrected Jesus"]." Frei, "Theology and the Interpretation of Narrative," 110-11.

${ }^{102}$ Knight, Liberalism versus Postliberalism, 281-82.
} 
set of structural difficulties in Knight's account-a series of misunderstandings of Frei's theology.

One problem of the meaning-as-use reductionism that Knight ascribes to Frei (in his Kripkensteinian portrayal of him) is that it falls squarely into the trap that Frei himself identified in the preface to his dissertation - of turning "thus sayeth the Lord into thus heareth the man."103 Frei, by contrast, says that the church, because it "is accountable to God for its discourse about God," must "undertake a critique and correction of her discourse in the light of the norm she sees as the presence of God to the Church, in obedience to God's grace." ${ }^{\prime 104}$ In other words-and this point is crucial-Frei does not simply reject "thus heareth the man" for a conception of "thus sayeth the Lord," as though scripture were like "a stone thrown down from Heaven" (as Paul Tillich caricatured Barth's account of revelation). Frei recognized that there is no human access to God unmediated by human social practices (linguistic, conceptual, sociological, historical and so forth). As George Hunsinger writes of Barth, "Since all our language inevitably arises from and is formed by the human and creaturely sphere, the question in speaking about God was not whether but how to be 'anthropomorphic'."105 Frei's career-long work can be viewed as a lengthy and leisurely unfolding of this "but how." The point is to avoid attempts to stand outside history, human language, and human concepts, as well as attempts to flatly assimilate God to ("shoe-horn God into"106) human socio-linguistic practices. The result in Frei's case is a theological critical realism about scripture and the church as the means in and through which God makes human social practices adequate for portraying God. And this renders the theological processes of critique and correction "in the light of the norm she sees as the presence of God to the Church, in obedience to God's grace" a perpetually-unfolding inquiry (i.e. "following Jesus at a distance"). This discourse of tradition persistently asks of itself: "Does Christian discourse come from [God] and move toward [God], and is it in accordance with [God]?"107

\section{Literal and Plain}

It is important to be clear about what Knight means when he speaks of "literal reading." In my judgment, Knight's account is not quite consistent with all that Frei says about it. Knight ascribes to Frei the view that, whichever sense the community takes to be authoritative becomes for that very reason "literal." ${ }^{108}$ Yet to ascribe this definition of "literal sense" to Frei is to miss certain subtle (but crucial) distinctions that Frei carefully makes throughout his writing.

\footnotetext{
${ }^{103}$ Barth to Harnack as quoted in Hans W. Frei, "The Doctrine of Revelation in the Thought of Karl Barth, 1909-1922: The Nature of Barth's Break with Liberalism" (PhD diss., Yale University, 1956).

${ }^{104}$ Frei, Types, 39.

${ }^{105}$ George Hunsinger, "Beyond Literalism and Expressivism," Disruptive Grace, 215.

${ }^{106}$ To borrow Kevin Hector's colorful phrase. Hector sets forth a compelling account of Frei's work that I consider to be consistent with the reading I forward here. See Kevin W. Hector, "Postliberal Hermeneutics: Narrative, Community, and the Meaning of Scripture," The Expository Times 122 no. 3 (December, 2010): 105-116.

${ }^{107}$ Frei, Types, 39.

108 "Thus what makes a particular sense of a biblical text the 'literal' sense is nothing other than the community's judgment (or the presupposition of certain of its actions) that this particular sense is authoritative. And a particular sense will be authoritative insofar as it enables the church to live out its mission." Knight, Liberalism versus Postliberalism, 208.
} 
First, Frei distinguishes between "plain sense" and "literal sense." The sense that some interpretive traditions in religious communities tend to reach consensus upon as authoritative is what Frei calls the "plain sense." The "literal sense" is one of the four-fold sense of Scripture (literal, spiritual, analogical, anagogical). The early church identified and grappled with these senses, and the literal sense became orientational (entry-level for the others). The "literal sense" was later identified as "adequately perspicuous" as a scriptural form of witness by the Protestant Reformers. ${ }^{109}$ As a historical matter of fact, of the four-fold approaches to reading scripture, the literal sense did emerge as authoritative from the early church forward. As such, the literal sense became the "plain sense."

Simple conflation of Frei's uses of the terms "literal" and "plain" might appear to be a minor error. The problem is that it neglects the important discussion that Frei offers of these points. Specifically, it overlooks the considerable emphasis he places on the complex process by which the "rule of faith" and "rule of truth" emerged in the early church's determining the scriptural canon in light of, and as consistent with, the story of what Jesus did, and who Jesus was. Frei says that the literal sense did not emerge as the plain sense for the early church as a matter of "logical necessity." Yet, it emerged nonetheless as that reading from which the rule of faith/rule of truth derived. Moreover, the rule of truth and rule of faith stood as independent norms over against Christian readings of scripture. That is, the rule of truth (as its name indicates) further exerted constraints upon what could count as truthful and faithful (note, not useful) readings of scripture. The literal sense became the plain sense (i.e., the authoritative and traditional sense) because of what the literal sense ascribes to Jesus-what it claims in witnessing to the lordship of Jesus Christ. In the literal sense of scripture "the singular agent enacting the unity of human finitude and divine infinity, Jesus of Nazareth, is taken to be itself the ground, guarantee, and conveyance of the truth of the depicted enactment." ${ }^{110}$ In other words, a precondition for the community's consensus that the literal sense ought to be plain was that the text's literal account ascribes the predicates that it does just to the person of Jesus. ${ }^{111}$ As such, these accounts could be recognized as portraying the truth about Jesus in accord with the apostolic witness (e.g. the centrality of "its sacred story, the life, teachings, death, and resurrection of Jesus of Nazareth"). ${ }^{112}$ The primacy accorded to the literal sense, Frei wrote elsewhere, reflects the church's recognition that these stories are adequate to portray this truth. It recognizes "the fitness and congruence of the 'letter' to be the channel of the spirit." ${ }^{\prime 13}$ This is what Frei means when he says, "In interpreting conceptually and existentially, we are governed first

\footnotetext{
${ }^{109}$ Frei describes these as follows: "There is the literal sense (what the text says), the allegorical sense (what we believe), the tropical sense (what we must do), and there is the anagogical sense (what we hope-or not hope)." Frei, "Conflicts in Interpretation," Theology E Narrative, 162.

${ }^{110}$ Frei, "Literal Reading," 143.

${ }^{111}$ Frei, "Conflicts in Interpretation," 164-5. "I take that to be the basic sense of what one means in the tradition of pre-critical New Testament interpretation as the 'literal sense.' That is, is it literally 'about' Jesus? Are certain descriptions literally ascribed, not are they literally descriptive, appropriately or rightly, but do they have for their subject matter this storied person? Jesus, and none other or no person but a concept? It is the literal ascriptiveness that is the basic sense of the literal it seems to me in the Christian tradition."

${ }^{112}$ Frei, "Literal Reading," 120

${ }^{113}$ Frei, "Theology and the Interpretation of Narrative," 108.
} 
by the story and, in the second place, by the way it functions in the Christian religion." 114

Knight's account, by contrast, seems to get this relation backwards. If I understand him correctly, Knight claims that whatever sense the community takes to be authoritative, in accord with what it understands to be its mission, becomes the literal sense. In other words, on Knight's reading, the preceding quotation from Frei ought to be rephrased: "We are governed first by the way the reading functions in the Christian religion and, in the second place, by the story." ${ }^{115}$ Frei (following the account of scriptural interpretation as explicatio, meditatio, applicatio) says the opposite-we are governed "first, by the story and, in the second place, by how it functions in the Christian religion." ${ }^{\prime 16}$

Knight arrives at this characterization only after treating Frei's exposition of three accounts of the literal sense in Frei's essay, "Theology and the Interpretation of Narrative," and then ascribing the third of these to him. But Frei never simply endorses what he identifies as the third example of literal reading. This becomes clearer by examining the different tasks that Frei takes up at different points in the essay. For instance, in what Frei labels as Part II of the essay, he undertakes an expository task of identifying the ways that the "literal sense" has been taken by Christian communities. Only here does he identify the three senses of "literal sense" that Knight makes so central to his reading of Frei.

As Knight points out, Frei says that "the third [sense of 'literal sense'] is especially closely related to theology in the second mode."117 Yet, Knight takes this point to constitute an unqualified endorsement of this third "literal sense." Moreover, Frei associates this "third sense" (i.e. "the way the text has generally been used in the community...the sense of the text in its sociolinguistic context-liturgical, pedagogical, polemical, and so on") with Wittgenstein: "This is the setting in which it is appropriate to reach for that saying of Wittgenstein that has so often and wrongly been given the status of a general principle." However, to characterize the "third sense" as "especially close" to the second mode of theology that Frei has in mind is not to say that the third sense belongs unequivocally to the second mode. For, Frei does not simply endorse this "third sense" of the literal sense outright and without qualification. In fact, when he turns to Section III of the essay he makes his own case for a particular account of the literal sense and explains the implications of such an understanding. But here Frei articulates a conception of the sensus literalis that expands upon what he had described as the "third sense" in Section II, that putative "full-blown understanding of meaning-as-use" that Knight ascribes to Frei. ${ }^{118}$ In fact, what Frei describes in Section III of his essay is best described as a complexly hybrid account of the second sense and the third sense. ${ }^{119}$

\footnotetext{
${ }^{114}$ Ibid., 113-14.

${ }^{115}$ Ibid., 113-14, my transposition according to Knight's description of the how the literal sense is whichever sense the community takes to be authoritative.

${ }^{116}$ Ibid., 114.

${ }^{117}$ Frei, "Theology and the Interpretation of Narrative," 103.

${ }^{118}$ Knight, Liberalism versus Postliberalism, 268

${ }^{119}$ Interestingly, Frei glosses this "third sense" in descriptive terms taken directly from Charles M. Wood's book The Formation of Christian Understanding: An Essay in Theological Hermeneutics (Philadelphia, PA: Westminster Press, 1981). See Frei, "Theology and the Interpretation of Narrative," 104-5. In taking Frei to embrace unequivocally this "third sense" of the literal sense, Knight considers his invocation of
} 
What difference does this make? To identify the text as an object around which scriptural practices cohere provides the basis on which Christian communities' scriptural practices are accountable to the features of the scriptural text, and thus, what the scriptural text portrays. Scripture does this uniquely in the context of the Christian community, for there it is recognized as scripture. ${ }^{120}$ This is to say-and Frei clearly says - that the socio-linguistic context of the Christian church is the context in which scripture takes on the uniquely authoritative significance that it has. But Frei immediately points out that this relationship is "asymptotic." What does he mean by this? It means that to recognize this text as scripture is to recognize its demand to submit to its claims and the content of what it says. And here we have arrived at the intrinsically Christological orientation of Frei's account of the literal sense: to recognize this text as scripture means to recognize the demand to subordinate oneself to what the text literally ascribes to this particular person Jesus"occurrences, teaching, personal qualities and religious attributes."121 Here again, I concur with Higton's claim that, for Frei, the church's taking the narrative reading of the Bible as primary is not to say that "the Church mastered the Bible." It is to say, rather, that "precisely by taking a narrative reading [i.e. the literal sense] as primary rather than an allegorical or purely symbolic one, the Church allowed the Bible to stand over against it as an independent norm which it could not control." ${ }^{122}$ But it becomes an independent norm even over what various Christian readers take scriptural texts to "mean." Higton continues:

This isn't just a contingent fact of history, said Frei. It came about precisely because Christians looked to the unsubstitutable man Jesus of Nazareth as their

Wood further evidence of Frei's dependence upon a Wittgensteinian understanding of meaning, because Frei once called the dissertation upon which Wood's book was based a "brilliant" exposition of Christian scriptural practices using some of Wittgenstein's terms (Knight, "Wittgenstein's Web," 337 n 3; 347 n 47). Of course, Frei was often generous in his praise to a fault. So, it is equally important to recognize that Frei was highly critical of Wood's book as well. Moreover, he criticized that book precisely because he thought it inadequately treated the constraints exerted by the content or object of Christian practices of understanding and engaging scripture. "The aspect [Wood] treats well is the exercise of Christian understanding... The aspect he does not really treat is the content or object of Christian understandings, viz., what it is about, and the relation of the latter to the exercise of that understanding. While there may not be any theory which adequately conceptualizes that relation between exercise and content, one responsibility of both theology and hermeneutics is to insure that the integrity of both is preserved, and that the appearance (or worse) of making one a vestigial appendage of the other at any point is avoided." Higton treats this point of criticism, and its significance in correcting the assimilation of Frei's view to the "third sense" of the literal sense in Mike Higton, Christ, Providence, and History (New York: T \& T Clark, 2004), 200-206 (here 203).

${ }^{120}$ The conception of scriptural practices Frei offers suggests that someone "outside" the Christian community could read the text and make claims about it that might very well correct beliefs of the socalled "insiders" concerning its proper meaning. Of course, Frei did not subscribe to the "insider/outsider" view of participation in the Christian communities, though Knight's ascription of a hermetically self-contained Christian "form of life" to Frei might imply as much. Frei spoke instead of the "pilgrim self" who was perpetually in passage within and between belief and unbelief, even in her best efforts to follow Jesus at a distance. See Hans W. Frei, The Identity of Jesus Christ: The Hermeneutical Bases of Dogmatic Theology (Eugene, OR: Wipf and Stock, 1997), 69-71, 129-31.

${ }^{121}$ Frei, "The 'Literal Reading' of Biblical Narrative," Theology E Narrative, 145. Of course, one need not be a Christian to recognize this text as Christian scripture. It is entirely possible for a non-Christian to recognize that this text is taken to be scripture without endorsing that claim herself (this is the de re / de dicto distinction). So claims about what the text ascribes to Jesus as scripture is not a claim that erects anything like an insider/outside dichotomy.

${ }^{122}$ Higton, "Frei's Christology and Lindbeck's Cultural-Linguistic Theory," 92. 
source and norm, and so learned to read their scriptures in such a way as to take them to be about that historically specific man....[Moreover]...this narrative reading is coherent with, informed by, and ultimately only intelligible on the assumption of, an incarnational theology.... ${ }^{123}$

This passage sketches well the central Christological orientation that Frei strove both to conceptualize and articulate over the course of his career. The Christian community's "recognition of the unsubstitutable man Jesus of Nazareth as their source and norm" was not just "useful" within their brute or given "form of life." Frei, rather, saw this as their response-their being acted upon and gathered by Christ through the work of the Holy Spirit. This recognition, of course, was a complex, sociohistorically situated process of discernment. It frequently occurred through debate and contestation over what the Scriptural texts mean. In fact, says Frei, it was a recognition about which they could have been wrong. ${ }^{124}$

Indeed, those interpretations that came to be recognized as erroneous were contested at length and, from time to time, rejected (or perhaps erroneously accepted). In other words, the community's "agreed use" was sometimes wrong, even though it had been recognized as authoritative for the community members for some time. But the community was anything but the "ultimate arbiter" of textual meaning through its "agreed use" of the text. It was rather accountable to the norms of its practices by which the text was deemed to be scripture in the first place. ${ }^{125}$ The church argued about what the text says, and about how it ought to be interpretedand, in the end, all of them could be wrong. As Frei points out, the rules for faithful or truthful reading that emerged in the early church "governed the Gospels' use in the church [and] asserted the primacy of their literal sense."126 Such rules, while largely informal, were not wholly so-they found formal encapsulation by the second century in the "rule of faith" or "rule of truth." And the deployment of these rules, he says, constituted the church's recognition of the normative priority of what the text (in its literal sense) ascribed to the person and work of Jesus Christ. ${ }^{127}$ What is most remarkable, however, is that this understanding of the literal reading took a minimalist form that permitted remarkable wide-ranging disagreement and diversity about the claims and meaning of scripture (and could include classical "liberal" readings such as the quest for the historical Jesus).

But precisely here it is important to recall that Frei's conception of the basic-ness of the Christian community within which particular texts are recognized as scripture differs from Wittgenstein's in fundamental ways. For Frei, Christian community is "given" only in the sense that it is gathered always and already in response to God's gracious initiative in the person and work (then and now) of Jesus Christ through the work of the Holy Spirit. The Christian community is a community by virtue of

${ }^{123}$ Ibid.

${ }^{124}$ The point is not simply "that there were reasons" (as Knight puts it), but rather, that the reasons were of a very specific sort, that the reasons (and norms) exerted a certain force independently of what the community's dispositions were, or even what the community believed to be the case.

${ }^{125}$ Frei, Types, 86-7. But, again, notice that the object-directedness of the practice pertains to claims about meaning (i.e. "our interpretations of a text"), and not simply questions of truth, contra Knight, "Wittgenstein's Web," 357.

${ }^{126}$ Frei, "Literal Reading," 122-23.

${ }^{127}$ Ibid., 122. 
being gathered by God, and in following Jesus. And this is why one cannot engage Frei's account of socio-linguistic context without recognizing the persistent Christological basis and orientation that centers Frei's work. This, I have argued, is the primary warrant for the Christian community's taking the literal sense to be the plain sense, and thus the authoritative one. ${ }^{128}$ This conviction reaches beyond the (Kripkensteinian) community level of agreement that Knight ascribes to Frei. But it also reaches beyond the congruity at the background level of social practices and empirical congruities which make explicit agreement possible, and to which that agreement is accountable (Wittgenstein). This is what it means to deem Frei's understanding of scriptural authority as Christologically determined and oriented.

\section{Conclusion}

Postliberal theology comprises a wide-ranging set of theological projects. ${ }^{129}$ Not all of them make use of Wittgenstein's work, nor need they. To appropriate Wittgenstein for theological purposes is not without its risks: Wittgenstein's later work has inspired wide-ranging critical literatures and philosophical controversies. Furthermore, not all readings of Wittgenstein are equal. And while Frei drew upon Wittgenstein's writings, he did not draw upon the Wittgenstein that Knight ascribes to him (i.e. Kripkenstein).

Frei's appropriations of theory were consistently delicate and ad hoc. His motivations were ultimately Christological at the same time his methodological work was richly and diversely theoretical. Nonetheless, perhaps there is a cautionary lesson here for any would-be postliberal theologian. For the philosophical controversies that swirl around Wittgenstein's work-though often deviating from what he actually

\footnotetext{
${ }^{128}$ On this point, I commend careful attention to the portion of my Toward a Generous Orthodoxy entitled "No Matter How Philosophers May View It" (chap. 8, 177-81). "So, there is far more at stake here than what the Christian community perceived to be beneficial, useful, or how the community decided to use the biblical text." This line follows on the heels of my quoting Frei's claim that "the conveyance of the truth of the depicted enactment" (for which "the singular agent enacting the unity of human finitude and divine infinity, Jesus of Nazareth, is taken to be itself the ground, guarantee, and conveyance") is what is at stake for Frei. Knight eliminates my quotation of Frei that indicates what is at stake. Instead, he positions my final statement of the paragraph (that there is, thus, more at stake than usefulness, beneficiality) as a free standing claim, and then chastises me for "not saying what more is at stake" (Knight, "Wittgenstein's Web,", 249-51). To restate this again, the "more" that is at stake-beyond communal use, beneficiality, or usefulness, is God's use of these to mediate the presence of Christ to the church through the Spirit. As I point out there, following Frei, "While 'what the text says' makes possible and warrants predicate ascription to the person of Jesus it does not ultimately govern that predicate ascription. The final warrant for seeing Jesus as the unsubstitutable ascriptive subject of the gospel narratives is the person of Christ himself. This is not merely Christ as a narratively deposited character in the story. It is Christ as the living person present even now. It is the person whose conscription of these concepts-as well as the practices that make predication, storytelling, writing, reading, and meaning possible in the first place-breaks and transforms them in order to thereby objectively, though analogically, mediate his person to believers. This is the sense in which engaging Scripture is irreducibly social-practical but theologically unique in kind. That is, while it is the text in and through which the literal sense is possible, it is, according to Frei, the living and present person of Christ who governs-and thereby warrants-the predicates ascribed to him in the literal sense of Scripture, not the consensus of the Christian community (even consensus understood as congruity at the level of their practices)" (Toward a Generous Orthodoxy, 178). This is, I argue, the primary warrant for the Christian community's taking the literal sense to be plain (authoritative). It reaches beyond not only Knight's (Kripkensteinian) community level of agreement, but also the congruity at the background level of social practices which make possible explicit agreement. This is the Christological feature of Frei's understanding of scriptural authority.

${ }^{129}$ See, for instance, Peter Ochs, Another Reformation: Postliberal Christianity and the Jews (Grand Rapids, MI: Baker Academic, 2011).
} 
wrote- interpose a degree of risk. They risk distracting from the theological motivation and substance of the theologian's work. In my view, Frei clearly avoided these difficulties. In doing so, nonetheless, he demonstrates a great challenge facing postliberal theological method-the challenge to strike a delicate balance between the orientational ground and goal of theology, and the eclectic and diverse approach to the theoretical borrowing that will be necessary for theological tasks. Frei both recognized and devoted much of his career to illuminating and enacting the fact that theologians, church people, and scholars bring their antecedent categories and presuppositions to the scriptural text. But if the theological task is truly to be captive to the Lordship of Christ, then the unavoidable theoretical categories (philosophical, anthropological, sociological, and so forth) must be oriented and ordered by the gracious presence of Christ in the work of the Holy Spirit, and thus be deployed in ad hoc ways.

Frei was not anti-theory. To the contrary, he saw it necessary to deploy whatever theories might aid Christological aims. He tirelessly insisted that theory is indispensable for theology-interposing the proviso, of course, that the inevitable, and indeed necessary, uses of theory for theology remain secondary to recognizing that the condition of theology's possibility is always and already God's action here and now (again and again).

Thus we find Frei "plead[ing] for the primacy of the literal sense and the puzzling but firm relationship to a truth toward which we cannot thrust." Such a view does not negate philosophical accounts of truth, meaning, or reference, in so far as such an account may prove helpful to his Christological purposes and commitments. But none can be established as "the necessary theory of meaning," as a sine qua non for the possibility of theology. As Frei put the point, "Any notion of truth [and we might here exchange the word 'truth' for 'meaning' and/or 'reference'] such that that concept disallows the condescension of truth to the depiction in the text-to its selfidentification with, let us say, the fourfold story of Jesus of Nazareth taken as an ordinary story-has itself to be viewed with profound skepticism by a Christian interpreter." ${ }^{130}$ In other words, the indispensable and inevitable uses of theory must be adequately piecemeal and properly oriented to permit room for an understanding in which "truth condescends to the text"-miraculously, mysteriously, and yet, genuinely. ${ }^{131}$

\footnotetext{
${ }^{130}$ Frei, "Conflicts in Interpretation," Theology \& Narrative, 164.

${ }^{131}$ I am grateful to Ben Dillon, George Hunsinger, Martin Kavka, and Jeffrey Stout for their suggestions and criticisms of earlier versions of this essay.
} 